\title{
Relationships between chemical structures and functions of triterpene glycosides isolated from sea cucumbers
}

\author{
Joo-In Park ${ }^{1 *}$, Hae-Rahn Bae ${ }^{2 *}$, Chang Gun Kim ${ }^{1,3}$, Valentin A. Stonik ${ }^{4}$ and Jong-Young Kwak ${ }^{1,3}{ }^{*}$ \\ ${ }^{1}$ Department of Biochemistry, Dong-A University, Busan, South Korea \\ ${ }^{2}$ Department of Physiology, School of Medicine, Dong-A University, Busan, South Korea \\ ${ }^{3}$ Immune-Network Pioneer Research Center, Dong-A University, Busan, South Korea \\ ${ }^{4}$ The Laboratory of Chemistry of Marine Natural Products, G. B. Elyakov Pacific Institute of Bioorganic Chemistry, Far-Eastern Branch of the Russian Academy of \\ Science, Vladivostok, Russia
}

Edited by:

Antonio Trincone, Consiglio

Nazionale delle Ricerche, Italy

Reviewed by:

Robert Vianello, Rudjer Boskovic

Institute, Croatia

Daniel Anthony Dias, The University

of Melbourne, Australia

\section{*Correspondence:}

Joo-In Park, Department of

Biochemistry, Dong-A University

College of Medicine, 32,

Daesin-gongwon-ro, Seo-Gu,

Busan 602-714, South Korea

e-mail:jipark@dau.ac.kr;

Hae-Rahn Bae, Department of

Physiology, Dong-A University

School of Medicine, 32,

Daesin-gongwon-ro, Seo-Gu,

Busan 602-714, South Korea

e-mail:hrbae@dau.ac.kr;

Jong-Young Kwak, Department of

Biochemistry, Immune-network

Pioneer Research Center, Dong-A

University School of Medicine,

Dong-A University, 32,

Daesin-gongwon-ro, Seo-Gu,

Busan 602-714, South Korea

e-mail: jykwak@dau.ac.kr
Many marine triterpene glycosides have in vitro and in vivo activities with very low toxicity, suggesting that they are suitable agents for the prevention and treatment of different diseases, particularly cancer. However, the molecular mechanisms of action of natural marine compounds in cancer, immune, and other various cells are not fully known. This review focuses on the structural characteristics of marine triterpene glycosides and how these affect their biological activities and molecular mechanisms. In particular, the membranotropic and membranolytic activities of frondoside $A$ and cucumariosides from sea cucumbers and their ability to induce cytotoxicity and apoptosis have been discussed, with a focus on structure-activity relationships. In addition, the structural characteristics and antitumor effects of stichoposide $C$ and stichoposide $D$ have been reviewed along with underlying their molecular mechanisms.

Keywords: triterpene glycosides, frondoside A, cucumarioside, stichoposides, anticancer activity, membrane transporters

\section{INTRODUCTION}

Many marine natural products have biological activities and low toxicity suitable for administration and exhibit wide diversity in their mechanisms of action. Glycosides, substances consisting of a sugar moiety attached to a triterpene or steroid aglycone, are widely distributed in plants. Triterpene glycosides are also found in marine invertebrates and are characteristic secondary metabolites of echinoderms, octocorals, and sponges (Stonik et al., 1999; Kalinin et al., 2008; Bordbar et al., 2011).

Stichoposide C (STC) (compound 1) and stichoposide D (STD) (compound 2) are hexaosides isolated from the holothurian Stichopus chloronotus (Figure 1) (Kitagawa et al., 1981; Stonik et al., 1982a). These compounds are also found in other representatives of the family Stichopodidae such as Thelenota ananas (Stonik et al., 1982b). The structural differences between STC and STD are a sugar residue; STC has quinovose, while STD has glucose as the second monosaccharide unit (indicated as the asterisk in compound 1 and 2). Frondoside A (compound 3) and cucumariosides are derived from the edible sea cucumbers Cucumaria frondosa and C. japonica, respectively (Girard et al., 1990; Stonik et al., 1999) (Figure 2). C. japonica is a source of several different cucumariosides such as cucumarioside $\mathrm{A}_{2}-2$ (compound 4), $\mathrm{A}_{4}-2$ (compound 5), and $\mathrm{A}_{7}-1$ (compound 6) (Figure 2) (Avilov et al., 1990; Drozdova et al., 1993, 1997; Stonik et al., 1999). Frondoside A and cucumariosides are pentaosides, with the main structural difference between the two compounds being the functional group at $\mathrm{C}-16$ of the aglycone (acetoxy or keto group) and the third carbohydrate unit in the carbohydrate chain (indicated by an asterisk in compound 3 and 4). Interestingly, despite such similar structures, the biological activity and mechanism of frondoside A and cucumariosides appear to differ.

This review highlights the structural characteristics and mechanisms of action of marine triterpene glycosides, such as stichoposides, frondoside A, and cucumariosides. The biological activities and molecular mechanisms of several additional marine triterpene glycosides that have been studied are summarized. 


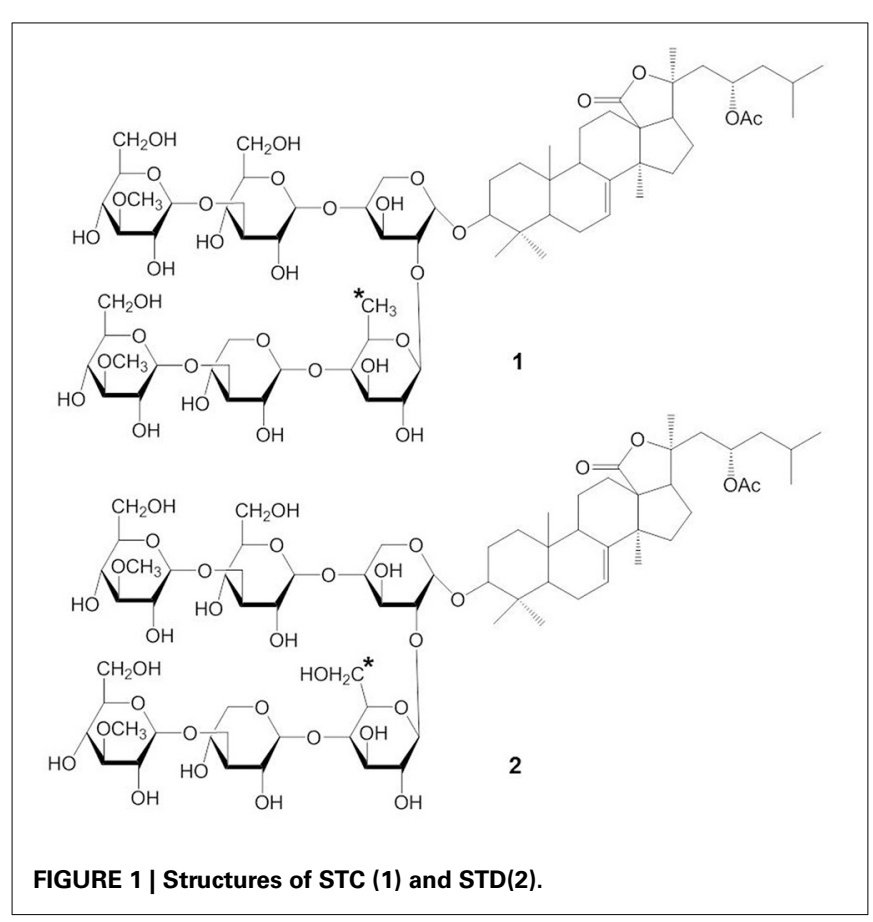

\section{THE STRUCTURAL CHARACTERISTICS OF MARINE TRITERPENE GLYCOSIDES}

Triterpene glycosides are the most abundant secondary metabolites in terrestrial plants and sea cucumbers. Marine triterpene glycosides are the predominant secondary metabolites of holothurians and are suggested to be responsible for their general cytotoxicity (Zhang et al., 2006a,b,c,d; Kim and Himaya, 2012; Colorado-Ríos et al., 2013). Last 20 years more than 100 new triterpene glycosides were isolated. Really, only by Russian group from Pacific Institute of Bioorganic Chemistry (PIBOC) at Vladivostok, about 30 new glycosides were isolated from Eupentacta (Cucumaria) fraudatrix (Silchenko et al., 2011, 2012a,b,c,d, 2013b,c), 14 new glycosides from Cucumaria frondosa (Girard et al., 1990; Silchenko et al., 2005a,b, 2007b), 7 from Stuarocucumis liouvillei (Antonov et al., 2008, 2011), 6 from Cladolabes schmeltzi (Silchenko et al., 2013d), 6 from Cucumaria okhotensis (Silchenko et al., 2007a, 2008), 5 from Synallactes nozawai (Silchenko et al., 2002), 5 from Actinocucumis typica (Silchenko et al., 2013a), 4 from Cucumaria conicospermium (Avilov et al., 2003), 3 from Mediterranean species (Silchenko et al., 2005c), 3 from Pentamera calcigera (Avilov et al., 2000a,b), 3 from Australostichopus (Stichopus) mollis (Moraes et al., 2005), 3 from Achlionice violaecuspidata (Antonov et al., 2009), 2 from Synapta maculata (Avilov et al., 2008), 1 from Cucumaria koriaiensis (Avilov et al., 1997), 1 from Psolus eximus (Kalinin et al., 1997), and so on. Several series of structures were also reviewed (Kalinin et al., 2012; Kim and Himaya, 2012). Reviews, completely described all the last glycosides were not yet published. Several early reviews are mentioned in our papers (Stonik et al., 1999; Kalinin et al., 2005). These are grouped into four main structural categories, based on their aglycone structures: $3 \beta$-hydroxyholost-9(11)-ene aglycone skeleton (structure 7), $9 \beta \mathrm{H}-3 \beta$-hydroxyholost-7-ene skeleton (structure 8 ), other holostane type glycosides and nonholostane glycosides (Figure 3) (Kim and Himaya, 2012).

Triterpene glycosides of holothurians typically have carbohydrates and triterpenoid moieties (Kerr and Chen, 1995; Bordbar et al., 2011). The triterpenoid moieties consist of lanostane derivatives (Zhou et al., 2005) where the majority belongs to the holostane type (Dang et al., 2007). Holostane type triterpene glycosides include a 3 $\beta$, 20S-dihydroxy-5 $\alpha$-lanostano-18(20)-lactone structural feature (structure 9). The glycone part of natural products isolated from the sea cucumbers consists of two to six sugar units and is linked to the $\mathrm{C}-3$ position of the aglycone unit (Chiludil et al., 2003; Kalinin et al., 2005). Quinovose, glucose, 3-O-methylglucose, xylose, and 3-O-methylxylose are the main sugars present in the carbohydrate moieties of these glycosides (Iñiguez-Martinez et al., 2005). In the structure of the oligosaccharide chain, the first monosaccharide unit is always a xylose, whereas 3-O-methylglucose or 3-O-methylxylose is always at the terminus. In some glycosides, sulfate groups are attached to the oligosaccharide chain. Most of these are mono-sulfated glycosides with a few occurrences of di- and tri-sulfated glycosides (Chiludil et al., 2003).

\section{MEMBRANOTROPIC AND MEMBRANOLYTIC EFFECTS OF TRITERPENE GLYCOSIDES}

Membranolytic effects such as increased membrane permeability, loss of barrier function, and the rupture of cell membrane are considered to be the basic mechanisms underlying a variety of biological activities exerted by triterpene glycosides from both sea cucumbers and higher plants. However, the molecular mechanisms of action of these compounds in biomembranes are not fully understood. The triterpene glycosides attach to cell membranes, interact with membrane lipids, and form glycosidesterol complexes in biomembranes, modulating the membrane microviscosity and the activities of embedded membrane proteins (Stonik et al., 1999; Pislyagin et al., 2012). The formation of multimeric channels in sterol-containing lipid bilayers by triterpene glycosides may also be a basic mechanisms involved in increasing the permeability of membranes to ions and peptides (Li et al., 2005).

Although there are many subtle structural and functional differences between marine and plant triterpene glycosides, knowledge from earlier research with plant triterpene glycosides suggests that marine triterpene glycosides may have similar effects on membranes. For example, extensive studies on the membranotropic effects of plant triterpene glycosides have been performed for decades, especially with natural compounds from Panax ginseng C.A. Meyer (Im and Nah, 2013). The structures of some pharmacologically important plant triterpene glycosides are shown in Figure 4. Ginsenosides or ginseng saponins are major pharmacologically active ingredients of ginseng, which are composed with an aglycone of a dammarane skeleton and one or more covalently linked sugar moieties (Nah, 2014). Ginsenoside $\mathrm{Rb}_{1}$ has two glucopyranosyl sugar chains at $\mathrm{C}$ 3 and C-20 positions, respectively (compound 10) (Figure 4). Ginsenoside Re has one glucose-rhamnose disaccharide moiety at C-6 position and one glucopyranosyl moiety at C-20 position (compound 11). Ginsenoside $\mathrm{Rg}_{3}$ has two glucopyranosyl 


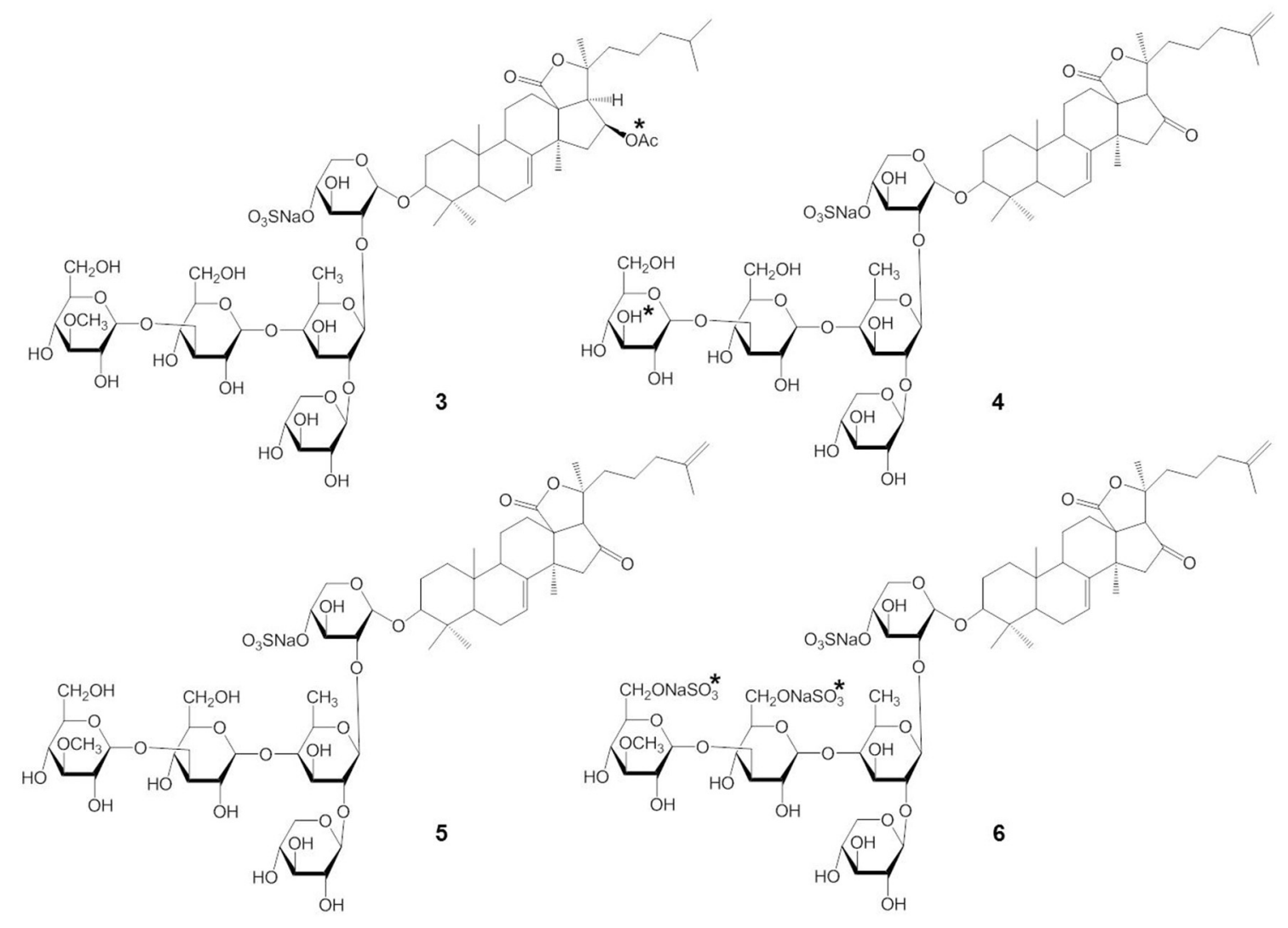

FIGURE 2 | Structures of frondoside A (3) and cucumariosides (4-6).

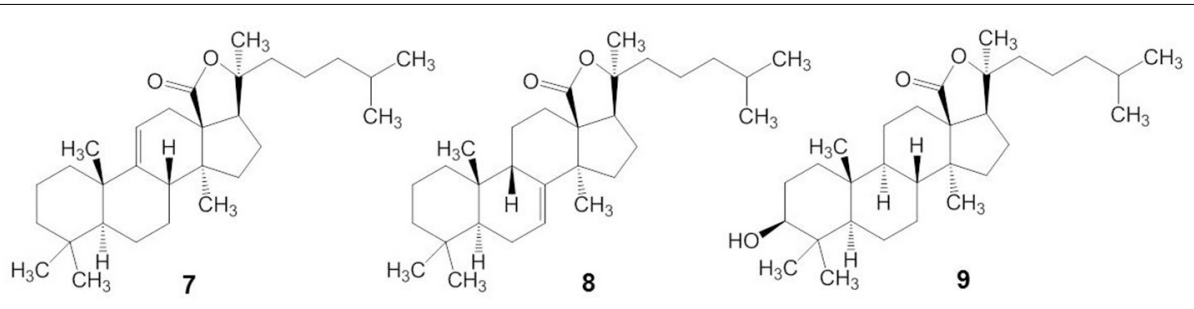

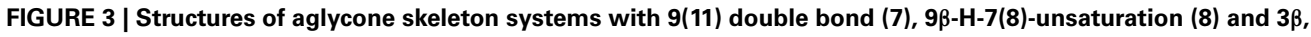
20S-Dihydroxy-5 $\alpha$-lanostano-18(20)-lactone (9).

sugar chains only at C-3 position (compound 12). Glycyrrhizin, the main sweet-tasting constituent of licorice root, consists of a disaccharide of two glucuronic acids linked at C-3 position of the pentacyclic triterpene aglycone, glycyrrhetinic acid (compound 13). Recently, a detailed mechanism for the membrane permeabilization induced by the triterpenoid monodesmosidic saponin, $\alpha$ - and $\delta$-hederin (triterpene saponins) has been proposed (Lorent et al., 2013). This mechanism includes three steps of cholesterol-independent binding to the membrane, interaction with cholesterol and asymmetric lateral distribution of saponin, and pore formation and budding of the lipid bilayer due to the increased curvature stress (Lorent et al., 2013).
More recently, at lower concentrations (in the nanomolar or low micromolar ranges) than those causing hemolytic and cytotoxic effects, the triterpene glycosides from marine sponges and sea cucumbers were found to act on specific membrane transport proteins and change their activities. For example, frondoside $\mathrm{A}$ and cucumarioside $\mathrm{A}_{2}-2$ inhibited the ATP-binding cassette $(\mathrm{ABC})$ transporter, multidrug-resistance protein-1 (MDR1) (Wink et al., 2012; Menchinskaya et al., 2013). Membrane transporters which are modulated by triterpene glycosides and thus can be proposed as potential therapeutic targets are summarized in Table 1. Although the majority of researches on the membranotropic effects were done with plant triterpene glycosides, understanding the reported targets of membrane transport 


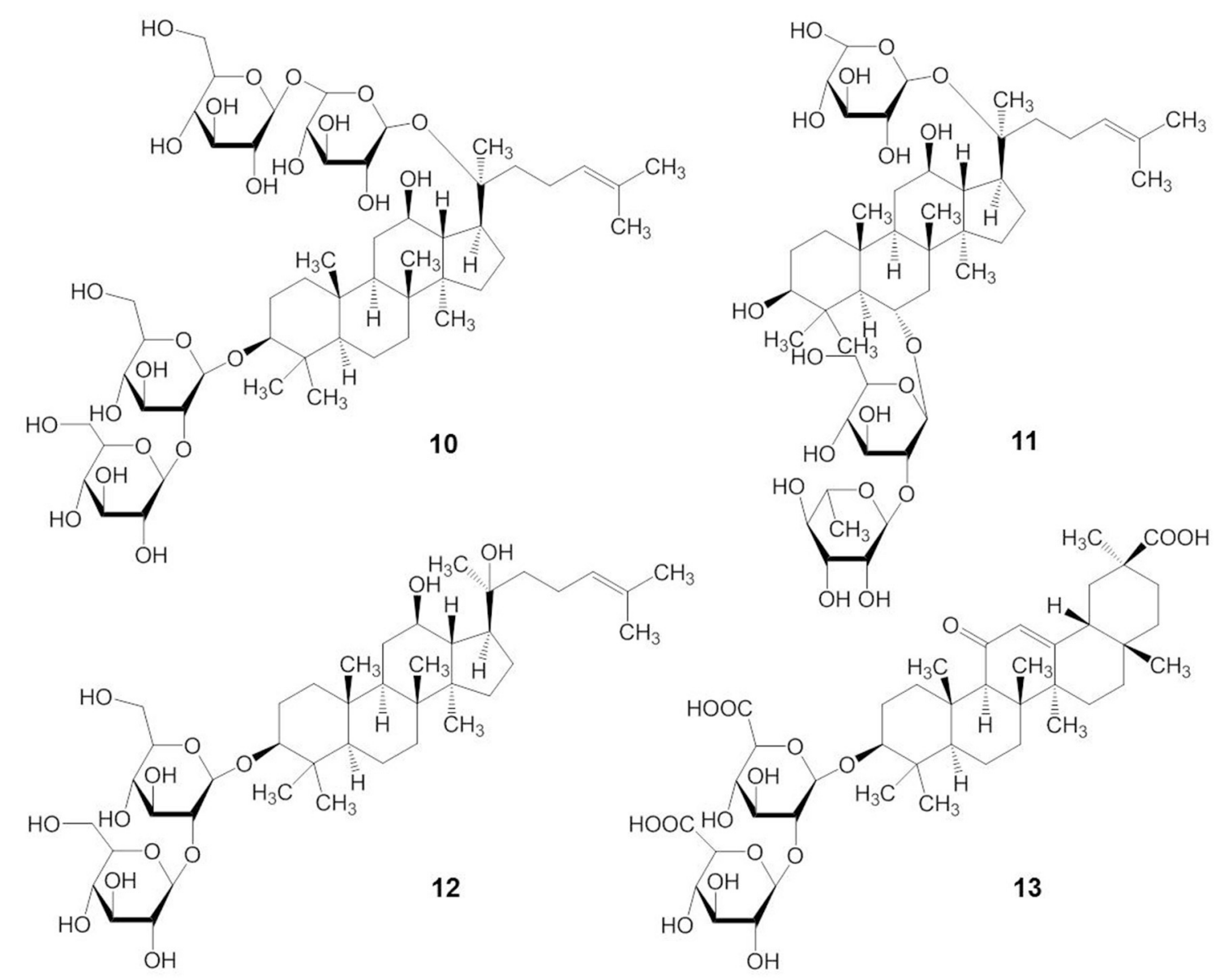

FIGURE 4 | Structures of plant triterpene glycosides.

proteins might provide a basis for the exploration of target molecules for marine triterpene glycosides and their development as drugs.

Selective inhibition of $\mathrm{Na}^{+}-\mathrm{K}^{+}$-ATPase and $\mathrm{Ca}^{2+}$-ATPase in sarcoplasmic/endoplasmic reticulum (SERCA), in combination with increased $\mathrm{Ca}^{2+}$ influx through L-type voltage-gated calcium channels, transient receptor potential canonical (TRPC) channels, and the ryanodine receptor led to an increase of cytosolic $\mathrm{Ca}^{2+}$ levels. This might explain the positive inotropic effect of triterpene glycosides (Gorshkova et al., 1999; Wang et al., 2008; Lin et al., 2012; Hwang et al., 2013; Wong et al., 2013). Furthermore, triterpene glycosides inhibited voltage-gated $\mathrm{Na}^{+}$channels ( $\mathrm{Na}_{\mathrm{V}} 1.2$ and $\mathrm{Na}$ 1.4) (Lee et al., 2008). In addition, triterpene glycosides could induce $\mathrm{K}^{+}$currents through voltage-gated $\mathrm{K}^{+}$channel $\left(\mathrm{K}_{\mathrm{V}} 1.4\right)$, calcium-activated $\mathrm{K}^{+}$channel $\left(\mathrm{BK}_{\mathrm{Ca}}\right)$, and human Ether-à-go-go Related Gene (hERG) $\mathrm{K}^{+}$ channels (Kv11.1), which might be responsible for their vasodilatory and antiarrhythmic effects (Lee et al., 2009; Choi et al., 2011a,b; Xu and Huang, 2012). The antiepileptic and neuroprotective effects of triterpene glycosides might be due to the inhibition of excitatory $N$-methyl-D-aspartate (NMDA) receptors and nicotinic acetylcholine receptors, as well as the activation of inhibitory $\gamma$-amino butyric acid (GABA) receptors (Lee et al., 2006, 2013a,b).

\section{ANTICANCER ACTIVITIES OF MARINE TRITERPENE GLYCOSIDES}

The antitumor action of the triterpene glycosides from sea cucumbers was discovered by Nigrelli (1952), and most of the marine triterpene glycosides that have been studied since that time are cytotoxic toward cancer cells. Nigrelli (1952) showed that injection of a "holothurin" solution inhibited the growth of Sarcoma-180 tumor cells and induced regression of the tumor. Injection of Krebs-2 ascitic tumor cells treated with holothurin into healthy mice failed to induce marked tumor growth up to 80 days (Sullivan et al., 1955). In addition, holothurin, which is a substance containing as a main constituent holothurin A, inhibited the growth of epidermal carcinoma (KB) tumor cells (Nigrelli et al., 1967).

Many triterpene glycosides from various species of sea cucumbers have diverse biological activities, including anticancer activity. For example, glycosides from 19 species of the families Holothuriidae and Stichopodidae (the glycosides in majority belong to holothurin A and B series) inhibited the growth 
Table 1 | Membrane transporters as potential targets of triterpene glycosides from sea cucumbers and plants.

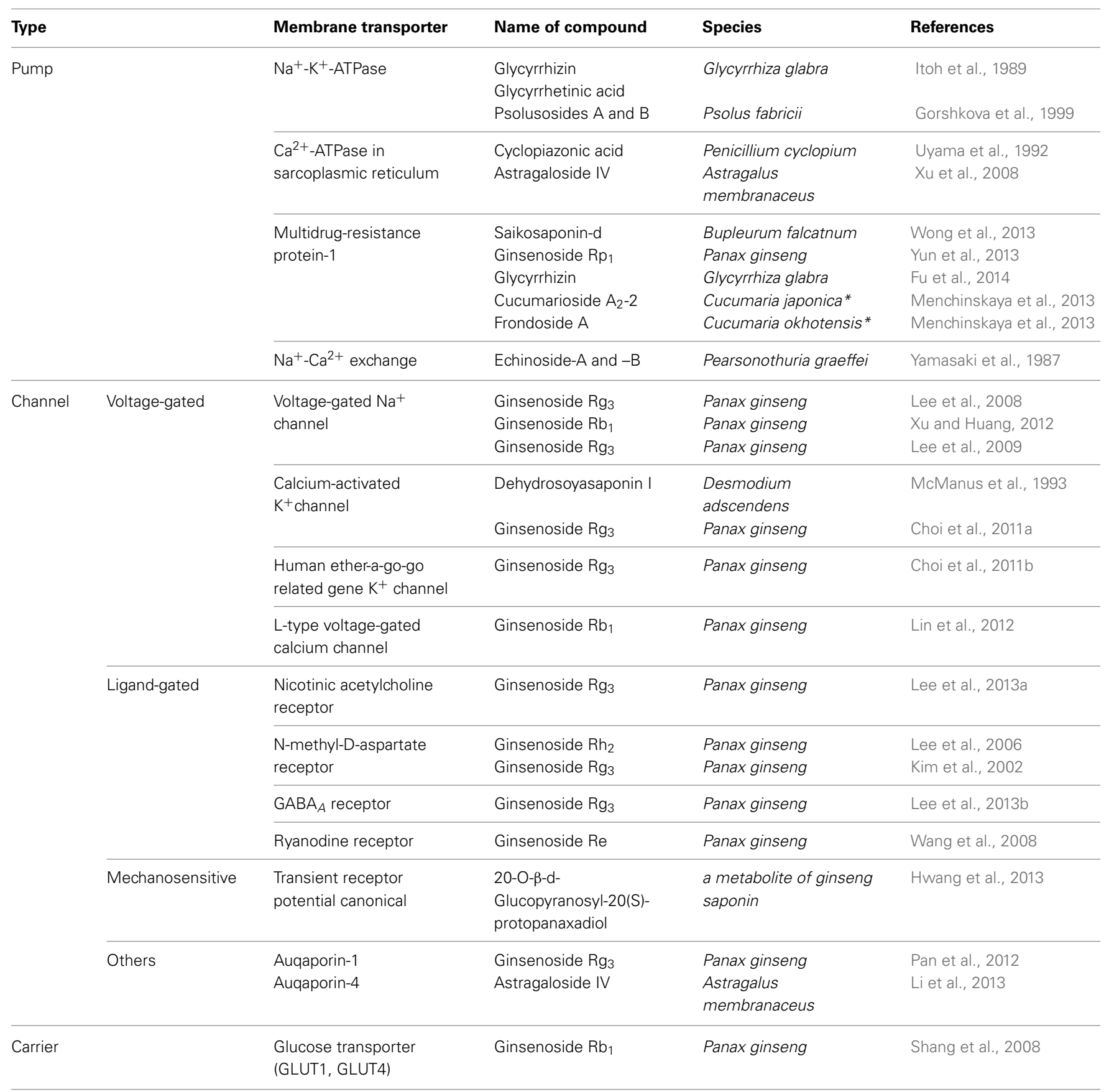

${ }^{*}$ Sea cucumbers.

of Sarcoma-37 cells at in vitro concentrations ranging from 6.2 to $100 \mu \mathrm{g} / \mathrm{ml}$ (Kuznetsova et al., 1982). Although the anticancer mechanisms of the triterpene glycosides have not been investigated in detail, the biologic actions, structure-activity relationships, and molecular mechanisms of stichoposide $\mathrm{C}$, frondoside $\mathrm{A}$, and cucumariosides have been most intensively studied (Aminin et al., 2001; Jin et al., 2009; Yun et al., 2012; Yun, 2014) and are discussed in the following sections. In addition, the potential molecular mechanisms of other triterpene glycosides have been described.

\section{STRUCTURE-ACTIVITY RELATIONSHIPS OF MARINE TRITERPENE GLYCOSIDES}

The molecular mechanisms of action of marine triterpene glycosides can be understood by uncovering the relationships between their structure and activities. However, the structure-activity relationships of marine triterpene glycosides have not been intensively studied. As shown in structure 14, the presence of an 18(20)-lactone in the aglycone, with at least one oxygen group nearby (indicated by an asterisk in structure 14), is significant for the biological activity of triterpene glycosides bearing a 
9(11)-double bond (Kitagawa, 1988) (Figure 5). Glycosides that have a 7(8)-double bond in their aglycone without a 16-keto group are more active in hemolytic test than those with a 16keto group (Kalinin et al., 1996). In general, the characteristics of the attached glycone structure may be related to the biological activities of the marine triterpene glycosides.

Many investigators have suggested that the bioactivity of the triterpene glycosides results from their strong membranolytic activity. It was reported that the membranolytic activity of triterpene glycosides was due to the formation of complexes between the glycosides and the 5(6)-unsaturated sterols within target cellular membranes (Kalinin, 2000). A linear tetrasaccharide chain of triterpene glycosides is necessary for the effects leading to modification of the cellular membrane (Kitagawa, 1988; Kalinin et al., 1992). Stichoposide A (STA) (compound 15), which had two monosaccharide units, and stichoposide E (STE) (compound 16), which has a xylose residue as the second monosaccharide unit (indicated by an asterisk in compound 16), had lesser membranotropic activity than other stichoposides (Kalinin et al., 2008) (Figure 6). Maltsev et al. (1985) reported that glycosides with quinovose as the second monosaccharide unit were more active hemolytics than other triterpene glycosides.

The presence or absence of a sulfate group in the sugar chain of triterpene glycosides influences their bioactivity (Kalinin, 2000; Kim and Himaya, 2012). A sulfate group at C-4 of the first xylose of non-branched glycosides with a linear tetrasaccharide

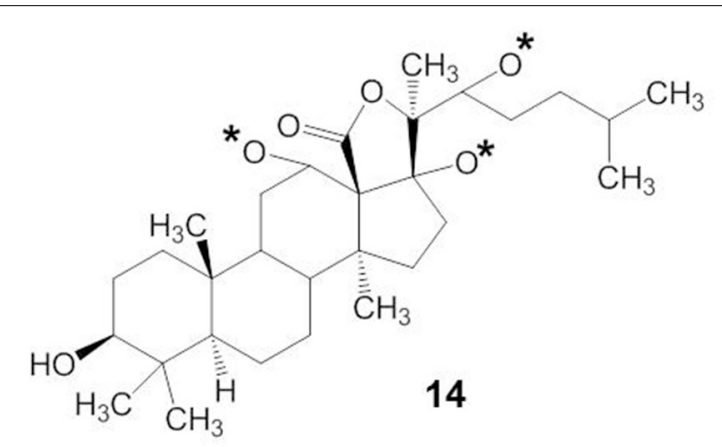

FIGURE 5 | Structures of 18(20)-lactone in the aglycone with oxygen group. unit (compound 17) does not significantly affect the activity of triterpene glycosides, but the absence of a sulfate group at C-4 of the xylose residue (compound 18) decreases their activity (indicated by an asterisk in compound 17 and 18) (Figure 7) (Kitagawa, 1988; Kalinin et al., 1992). In contrast, the presence of a sulfate at C-4 of the first xylose in branched pentaosides with 3$O$-methyl group on the terminal monosaccharide increases their activities, while the same sulfate decreases the activity of branched pentaosides that have glucose as the terminal residue. Sulfate groups attached to the C-6 position of terminal glucose or 3$\mathrm{O}$-methylglucose residues in triterpene glycosides greatly reduce their activity (Kalinin, 2000; Kim and Himaya, 2012).

\section{STICHOPOSIDES}

STC

STC (also called stichloroside C1) is a quinovose-containing hexaoside, originally isolated from the holothurian S. chloronotus (Kitagawa et al., 1981; Stonik et al., 1982a) but is also found in other representatives of the family Stichopodidae such as T. ananas (Stonik et al., 1982b). STC has quinovose as the second monosaccharide unit. The antitumor activity of STC appears to be related to its membranotropic effects (Kalinin et al., 2008). We previously reported that STC induced apoptosis of human leukemia and colorectal cancer cells through the activation of both intrinsic and extrinsic pathways (Yun et al., 2012). Anticancer agents increase ceramide levels, to variable extents, in all types of cancer cells (Taha et al., 2006). Ceramide is generated either by de novo synthesis or by sphingomyelin hydrolysis through the action of several types of sphingomyelinase (SMase) such as acid, neutral, or alkaline SMase (Strum et al., 1997; Brown and London, 1998; Kolesnick et al., 2000; Hannun and Obeid, 2008). Both acid and neutral SMase are involved in ceramide generation in response to apoptotic stimuli (Levade and Jaffrezou, 1999; Goni and Alonso, 2002; Gulbins and Kolesnick, 2002). Moreover, under conditions where the classical apoptotic pathway fails, intracellular generation of ceramide may function as part of a backup system that enables caspase-independent programmed cell death (Taha et al., 2006). We demonstrated that STC induced apoptosis through the generation of ceramide by the activation of acid and neutral SMases (Yun et al., 2012). Therefore, the target of STC seems to be SMase leading to increases in ceramide and apoptosis.

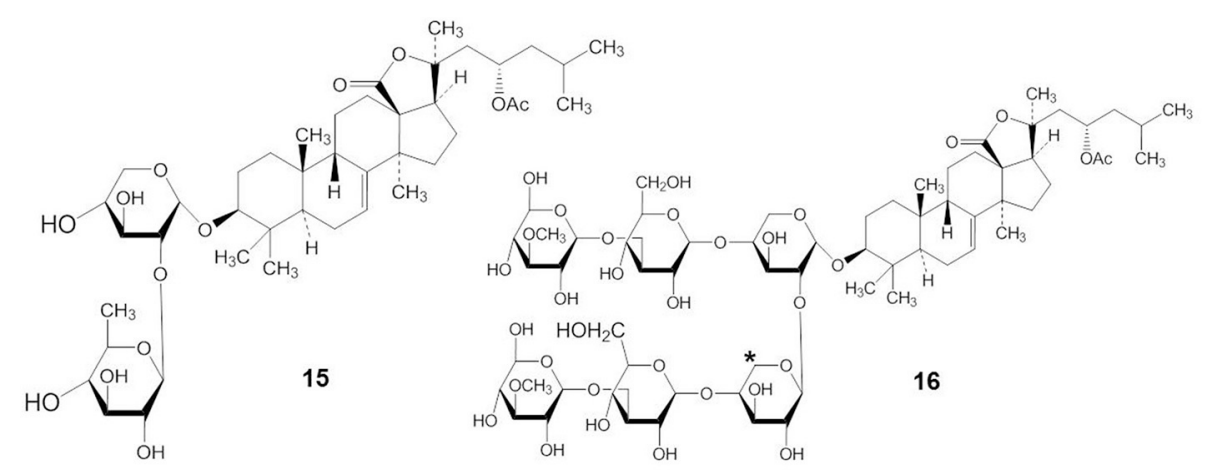

FIGURE 6 | Structures of STA (15) and STE (16). 


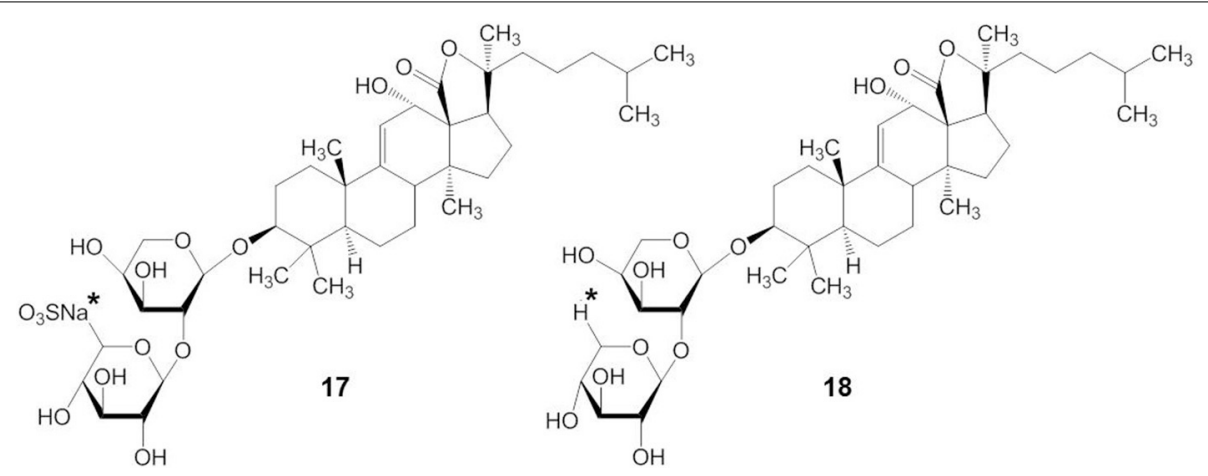

FIGURE 7 | Structure of compound with (17) or without (18) a sulfate group at C-4 of the xylose residue.

STD

STD is a hexaoside containing glucose at the second monosaccharide unit. We have shown that STD can induce apoptosis of human leukemia cells via the extrinsic and intrinsic pathways (Park et al., 2012a). We previously compared the potency of STC and STD in the induction of apoptosis using human leukemia K562 and HL-60 cells. STC was two to five times more potent than STD in inducing cell death $\left[\mathrm{IC}_{50}=0.5\right.$ (K562 cells) and 0.3 (HL-60 cells) $\mu \mathrm{M}$ for STC; 1.0 (K562 cells), and 1.5 (HL-60 cells) $\mu \mathrm{M}$ for STD] (Park et al., 2012a). These results are consistent with the relative membranotropic activities of STC and STD, suggesting that their anticancer activities may be related to their membranotropic activities. More importantly, STC and STD did not have any toxicity in normal hematopoietic progenitor cells or in a mouse tumor model (Yun et al., 2012; Yun, 2014).

It was shown that STD induced apoptosis by activating ceramide synthase 6 (CerS6) and increasing cellular levels of ceramide (Yun, 2014). The activation of CerS6 appears to be subsequent to the activation of the death receptor Fas (CD95) by STD (Yun, 2014). These results suggest that the difference in only one sugar between STC and STD may influence both the potency and the molecular mechanisms for their activities. However, further studies on the relationship between the structure and the activity of these molecules are needed to improve the efficacy and safety of these compounds in treating cancer patients.

\section{FRONDOSIDE A AND CUCUMARIOSIDES BIOLOGICAL ACTIONS OF FRONDOSIDE A AND THE CUCUMARIOSIDES}

Frondoside A has a sulfate, an acetoxy group at C-16 of the aglycone, penta-saccharide chain with xylose as the third monosaccharide residue, and 3-O-methylglucose as the terminal monosaccharide residue (Girard et al., 1990). Cucumarioside $\mathrm{A}_{4}$-2 has a 16-keto group in the aglycone and a glucose residue as the third monosaccharide unit in the carbohydrate chain (Kalinin et al., 1992, 1996). Cucumarioside $\mathrm{A}_{2}-2$ has 3-Omethylglucose instead of glucose as the terminal monosaccharide unit. Cucumarioside $\mathrm{A}_{2}-2$ is probably biogenetically connected with $A_{4}-2$ (Kalinin et al., 1992). Therefore, the main structural differences between frondoside $\mathrm{A}$ and the cucumariosides, as shown in Figure 2, are in a functional group at C-16 of the aglycone and the third carbohydrate unit in the carbohydrate chain.
Frondoside A and cucumariosides show anticancer activities in vitro and suppress tumor growth in vivo (Tian et al., 2005; Tong et al., 2005; Li et al., 2008). The antitumor activity of frondoside $\mathrm{A}$ and cucumariosides is a result of their activity to induce apoptosis of cancer cells (Li et al., 2008; Jin et al., 2009; Roginsky et al., 2010), including HL-60, NB-4, and THP-1 leukemic cells (Jin et al., 2009).

The cancer inhibitory effect of frondoside A in tumor-bearing mice might partly result from other biological activities, including its antiangiogenic and antimetastatic effects (Li et al., 2008; Al Marzouqi et al., 2011; Ma et al., 2012; Attoub et al., 2013). In addition, frondoside $\mathrm{A}$ inhibited the invasion of breast cancer cells via its ability to decrease matrix metalloproteinase (MMP)-9 expression through inhibition of nuclear translocation and transactivation of NF- $\mathrm{KB}$ and AP-1 (Park et al., 2012b). Park et al. (2012b) also showed that frondoside A significantly inhibited PI3K/Akt, ERK-1/2, and p38 MAPK activation in 12-Otetradecanoyl-phorbol-13-acetate (TPA)-stimulated breast cancer cells, indicating that frondoside A inhibited TPA-induced NF- $\mathrm{B}$ and AP-1 activation via inactivation of the PI3K/Akt, ERK1/2 and p38 MAPK pathways. Frondoside A also decreased AP-1-dependent transcriptional activities in JB6-LucAP-1 cells (Silchenko et al., 2008).

It is well established that prostaglandin E receptor, $\mathrm{EP}_{4}$ that is expressed in a number of different malignancies, can promote the migration of tumor cells in vitro (Timoshenko et al., 2003; Wang and Dubois, 2010). $\mathrm{EP}_{4}$ also promotes the invasive behavior of inflammatory breast cancers, one of the more aggressive forms of breast cancers (Robertson et al., 2010). Frondoside A inhibited metastasis of breast cancer cells by antagonizing $\mathrm{EP}_{4}$ and $\mathrm{EP}_{2}(\mathrm{Ma}$ et al., 2012).

Cucumariosides increased the lysosomal activity and intracellular $\mathrm{Ca}^{++}$concentrations of macrophages. These effects are related to the chemical structures of the molecules. For example, although there was no direct correlation, Silchenko et al. (2013c) suggested that the lysosomal activity and cytotoxicity of cucumarioside depended on features of both the aglycone and the carbohydrate chain. Holt et al. (2012) have investigated the effect of frondoside A on NK cells and demonstrated that prostaglandin $\mathrm{E}_{2}\left(\mathrm{PGE}_{2}\right)$ significantly suppressed the secretion of interferon- $\gamma$ $(\mathrm{IFN} \gamma)$ from NK cells while frondoside A restored the capacity of $\mathrm{NK}$ cells to secrete IFN $\gamma$ in the presence of $\mathrm{PGE}_{2}$. Other 
studies reported that in vitro treatment of peritoneal macrophages with cucumarioside $\mathrm{A}_{2}-2$ stimulated cell adhesion as well as their spreading reaction and motility (Aminin et al., 2011), whereas frondoside A suppressed MMP-9 enzymatic activity, secretion, and expression in MBA-MB-231 human breast cancer cells, leading to inhibition of invasion and migration of these cells (Park et al., 2012b). Therefore, it is important to compare the effects of frondoside $A$ and cucumariosides on the migration and spreading of various kinds of cells, including cancer and immune cells.

\section{EFFECTS OF SULFATE GROUPS ON THE HEMOLYTIC ACTIVITY OF CUCUMARIOSIDES}

The structures of the aglycone and carbohydrates in cucumariosides may confer membranolytic activity (Stonik et al., 1999). Kalinin et al. (1996) demonstrated that the membranolytic properties of cucumariosides correlated with their cytotoxicity to tumor cells. Cucumarioside $\mathrm{A}_{2}-2$ had in vitro cytotoxic and hemolytic effects on sea urchin embryos with $\mathrm{EC}_{50 s}$ of 0.45 and $5 \mu \mathrm{g} / \mathrm{mL}$, respectively (Aminin et al., 2006, 2010). The $\mathrm{LD}_{50}$ of cucumarioside $\mathrm{A}_{2}-2$ for mice was $10 \mathrm{mg} / \mathrm{kg}$ after intraperitoneal injection (Polikarpova et al., 1990). The membranolytic action of cucumariosides may be mediated through formation of molecular complexes with sterols in membranes and subsequent generation of solitary ion channels and large aqueous pores (Anisimov, 1987; Verbist, 1993; Kalinin et al., 2008). In addition, the glycosides effectively increased the microviscosity of the lipid bilayer of cell membranes (Pislyagin et al., 2012).

Marine triterpene glycosides contain different numbers of sulfate groups bound with sugars. Cucumarioside $\mathrm{A}_{2}-2$ has a sulfate group at C- 4 of the first xylose residue and cucumarioside $\mathrm{A}_{6}-2$ has an additional sulfate group at C-6 of the terminal 3-Omethylglucose residue. The hemolytic activity of cucumarioside $\mathrm{A}_{2}-2$ was significantly greater than its desulfated derivative and was higher than that of cucumarioside $\mathrm{A}_{6}-2$ (Kalinin et al., 1996). Moreover, cucumarioside $\mathrm{A}_{2}-2$ had more active hemolytic activity than cucumarioside $A_{3}$, which has an additional sulfate group at C-6 of the third monosaccharide unit (Kalinin et al., 1996). The increase in intracellular $\mathrm{Ca}^{2+}$ concentrations was also influenced by the number and positions of sulfate groups in the carbohydrate moiety of the molecules. Cucumarioside $\mathrm{A}_{2}-2$ was more active in inducing a rapid increase in cytosolic $\mathrm{Ca}^{2+}$ content, when compared to the poly-sulfated derivative of $\mathrm{A}_{2}-2$, cucumarioside $A_{7}-1$ (indicated by an asterisk in compound 5) (Agafonova et al., 2003). In addition, the mono-sulfated cucumariosides $A_{2}-2$ and $\mathrm{A}_{4}-2$ stimulated peritoneal macrophage lysosomal activity, while desulfation of their carbohydrate moiety completely abolished this activity (Aminin et al., 2001). Therefore, the hemolytic and cytotoxic activities of triterpene glycosides may be dependent on the positions of sulfate groups attached to the carbohydrates.

\section{CYTOTOXIC EFFECTS OF FRONDOSIDE A AND CUCUMARIOSIDES ON CANCER CELLS}

Frondoside A showed potent cytotoxicity against various cancer cells, including HeLa, HL-60, and lung cancer cells such as LNM35, A549, and NCI-H460-Luc2 (Silchenko et al., 2008; Jin et al., 2009; Attoub et al., 2013). Moreover, frondoside A enhanced the inhibition of lung tumor growth induced by the anticancer agent, cisplatin (Attoub et al., 2013). The $\mathrm{IC}_{50}$ of frondoside A in HL-60 cells was approximately 5- to 10- fold lower than that of cucumarioside $\mathrm{A}_{2}-2$ (Jin et al., 2009), although the in vivo toxicity of these two compounds for mice was similar (Polikarpova et al., 1990; Aminin et al., 2001). Overall, the structures of both the aglycone and the carbohydrate chain seem to be very important for the cytotoxic activity of frondoside A and the cucumariosides against cancer cells. However, some changes in the carbohydrate residues may not play a significant role in the cytotoxicity of triterpene glycosides because the cucumarioside $\mathrm{A}_{2}-2$ and cucumarioside $\mathrm{A}_{4}-2$ differ only in the structure of their terminal monosaccharide residue having glucose and methylglucose, respectively.

Silchenko et al. (2012d) suggested that amphiphilicity might affect the cytotoxic potency of cucumarioside by demonstrating that the presence of a $25-\mathrm{OH}$ group in the aglycone moiety of triterpene glycosides (cucumarioside $\mathrm{H}_{2}$ ) (indicated by an asterisk in compound 19) significantly decreased their cytotoxicity, but the cucumarioside having 25-ethoxy group (cucumarioside $\mathrm{H}_{4}$ ) had potent cytotoxic activity against lymphocytes and very high hemolytic activity (Figure 8). Our study suggested that the acetyl group at C-16 of the aglycone moiety might play a significant role in the cytotoxicity of triterpene glycosides because frondoside $\mathrm{A}$ had more potent effects than cucumarioside $\mathrm{A}_{2}-2$ (Jin et al., 2009). In contrast, the presence of acetyl groups in steroids increased their cytotoxic potency (Mimaki et al., 2001).

\section{APOPTOTIC EFFECTS OF FRONDOSIDE A AND CUCUMARIOSIDES ON CANCER CELLS}

Frondoside A caused a concentration-dependent reduction in the viability of lung cancer cells (LNM35, A549, and NCIH460-Luc2), melanoma cells (MDA-MB-435), breast cancer cells (MCF-7), and hepatoma cells (HepG2) over $24 \mathrm{~h}$, and increased the activities of caspases-3 and -7 in LNM35 lung cancer cells (Attoub et al., 2013). It was also shown that treatment of human pancreatic cancer cells with a low concentration of frondoside $\mathrm{A}$ induced apoptosis through increased activities of caspases-9, -3 , and -7 , increased bax, and decreased bcl-2 and

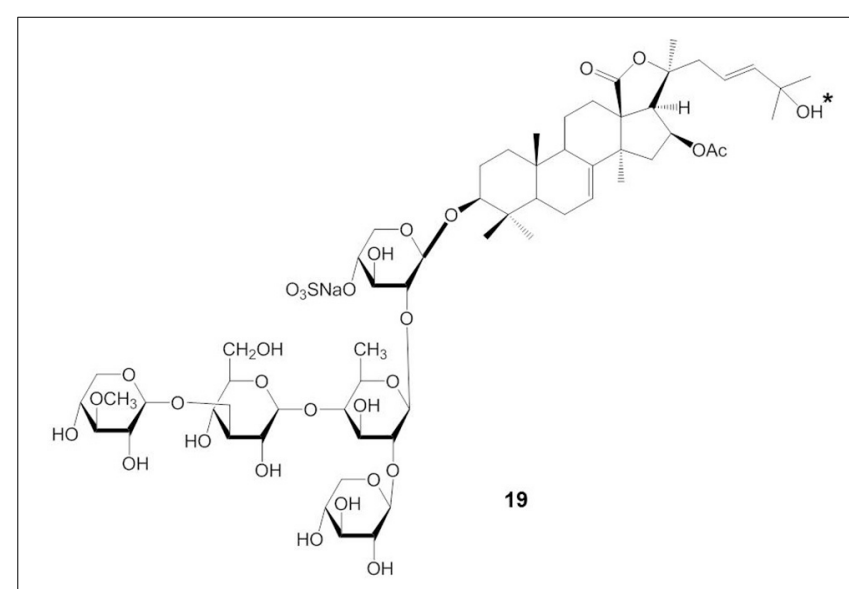

FIGURE 8 | Structure of cucumarioside $\mathrm{H}_{2}$ having 25-OH group. 
mcl-1 (Li et al., 2008). Our results demonstrated that mitochondrial membrane permeability was not changed, and the accumulation of cytochrome $\mathrm{c}$ in the cytosolic fraction was not observed in HL-60 cells treated with frondoside A (Jin et al., 2009). Similarly, frondoside A had more potent effects than cucumarioside $\mathrm{A}_{4}-2$ on apoptosis in leukemic cells but did not induce caspase activation before early apoptosis, whereas cucumariosides $\mathrm{A}_{2}-2$ and $\mathrm{A}_{4}-2$ showed similar effects on procaspase cleavage and mitochondrial permeability (Jin et al., 2009). Moreover, the annexin- $\mathrm{V}$ positivity induced by frondoside A was not inhibited by the pancaspase inhibitor, zVAD-fmk, whereas both the annexin- $\mathrm{V}$ positivity and cleavage of caspases induced by cucumarioside $\mathrm{A}_{2}-2$ were efficiently blocked by zVAD-fmk. These results suggest that frondoside $\mathrm{A}$ initiates apoptosis in a caspaseindependent manner in some cancer cells. Determination of the structural characteristics responsible for the differential effects of frondoside A and cucumariosides on inducing apoptosis in cancer cells will be essential to reveal their mechanisms of action.

\section{OTHER MARINE TRITERPENE GLYCOSIDES}

Previous studies demonstrated that marine triterpene glycosides from sea cucumbers had anticancer activities (Stonik, 1986; Stonik et al., 1999). However, the molecular mechanisms for their anticancer activities were only partly defined. Here, we briefly review potential molecular mechanisms for the anticancer activity of several marine triterpene glycosides. A summary of this information is shown in Table 2.

\section{ECHINOSIDE A AND DS-ECHINOSIDE A}

Echinoside A (EA) and DS-echinoside A (DSEA) belong to the holostane glycoside type with an 18(20)-lactone. Both have identical aglycone structures and there are only small structural

Table 2 | Potential molecular mechanisms for anticancer activity of marine triterpene glycosides.

\begin{tabular}{|c|c|c|c|c|c|}
\hline Name & Species & Actions & Molecular mechanisms & $I_{50}$ & References \\
\hline \multirow[t]{10}{*}{ Frondoside A } & Cucumaria frondosa & Inhibition of proliferation & Increased expression of p21 & $4 \mu \mathrm{g} / \mathrm{mL}$ (AsPC-1 cells) & Li et al., 2008 \\
\hline & & Induction of apoptosis & Caspase-independent pathway, & $1 \mu \mathrm{M}(\mathrm{HL}-60$ cells $)$ & Jin et al., 2009 \\
\hline & & & mitochondrial pathway, & 2. $5 \mu \mathrm{M}$ (MDA-MB 231 & \\
\hline & & & increased expression of p53 & cells) & Al Marzouqui \\
\hline & & & Decreased expression of $\mathrm{Bcl}-1$ & $4 \mu \mathrm{g} / \mathrm{mL}$ (AsPC-1 cells) & et al., 2011 \\
\hline & & & and $\mathrm{Mcl}-1$, increased expression & & \\
\hline & & & of Bax & & \\
\hline & & Antimetastatic activity & Inhibition of MMP-9 activation & $1 \mu \mathrm{M}$ (MDA-MB-231 & Li et al., 2008 \\
\hline & & & Inhibition of prostaglandin & cells) & Park et al., 2012b \\
\hline & & & receptors $\mathrm{EP}_{4}$ and $\mathrm{EP}_{2}$ & $0.5 \mu \mathrm{M}$ (Line 66.1 cells) & Ma et al., 2012 \\
\hline \multirow[t]{3}{*}{ Stichoposide C } & Thelenota anax & Induction of apoptosis & Extrinsic and intrinsic pathway, & $0.3 \mu \mathrm{M}$ (HL-60 cells) & Yun et al., 2012 \\
\hline & & & activation of acid SMase and & $0.5 \mu \mathrm{M}$ (K562 cells) & \\
\hline & & & $\begin{array}{l}\text { neutral SMase, ceramide } \\
\text { generation }\end{array}$ & & \\
\hline
\end{tabular}

\begin{tabular}{|c|c|c|c|c|c|}
\hline Stichoposide D & Thelenota anax & Induction of apoptosis & $\begin{array}{l}\text { Extrinsic and intrinsic pathway, } \\
\text { activation of ceramide synthase } \\
6 \text {, ceramide generation }\end{array}$ & $\begin{array}{l}1.5 \mu \mathrm{M}(\mathrm{HL}-60 \text { cells }) \\
1.0 \mu \mathrm{M}(\mathrm{K} 562 \text { cells })\end{array}$ & $\begin{array}{l}\text { Park et al., 2012a } \\
\text { Yun, } 2014\end{array}$ \\
\hline $\begin{array}{l}\text { Cucumaioside } \\
A_{2}-2, A_{4}-2\end{array}$ & Cucumaria japonica & Induction of apoptosis & Caspase-dependent pathway & $3 \mu \mathrm{M}(\mathrm{HL}-60$ cells) & Jin et al., 2009 \\
\hline Echinoside A & $\begin{array}{l}\text { Holothuria nobilis } \\
\text { Peasonothuria graeffei }\end{array}$ & $\begin{array}{l}\text { Induction of apoptosis } \\
\text { Cell cycle arrest }\end{array}$ & $\begin{array}{l}\text { Inhibition of the noncovalent } \\
\text { binding of topoisomerase } 2 \alpha \text { to } \\
\text { DNA } \\
\text { Increased expression of } p 16 \text {, } \\
p 21 \text {, and c-myc, decreased } \\
\text { expression of cyclin D1 }\end{array}$ & $\begin{array}{l}2.4 \mu \mathrm{M} \text { (human cancer } \\
\text { cell lines) } \\
2.7 \mu \mathrm{M} \text { (HepG2 cells) }\end{array}$ & $\begin{array}{l}\text { Li et al., } 2010 \\
\text { Zhao et al., } 2012\end{array}$ \\
\hline Ds-echinoside A & Peasonothuria graeffei & Antimetastatic activity & $\begin{array}{l}\text { Inhibition of NF-кB dependent } \\
\text { MMP-9 and VEGF expression }\end{array}$ & $2.7 \mu \mathrm{M}$ (HepG2 cells) & Zhao et al., 2011 \\
\hline Philinopside A & Pentacta quadrangularis & Induction of apoptosis & $\begin{array}{l}\text { Inhibition of receptor tyrosine } \\
\text { kinase autophosphorylation }\end{array}$ & $\begin{array}{l}1.5-2.4 \mu \mathrm{M} \text { (Sarcoma } \\
\text { 180, BEL-7402, MCF-7 } \\
\text { cells) }\end{array}$ & Tong et al., 2005 \\
\hline Philinopside E & Pentacta quadrangularis & Antimetastatic activity & $\begin{array}{l}\text { Inhibition of VEGFR2 signaling } \\
\text { Inhibition of interaction between } \\
\text { KDR and } \alpha_{v} \beta_{3} \text { integrin }\end{array}$ & $\begin{array}{l}\sim 4 \mu \mathrm{M} \\
2.5 \mu \mathrm{M}\end{array}$ & $\begin{array}{l}\text { Tian et al., } 2005 \\
\text { Tian et al., } 2007\end{array}$ \\
\hline
\end{tabular}




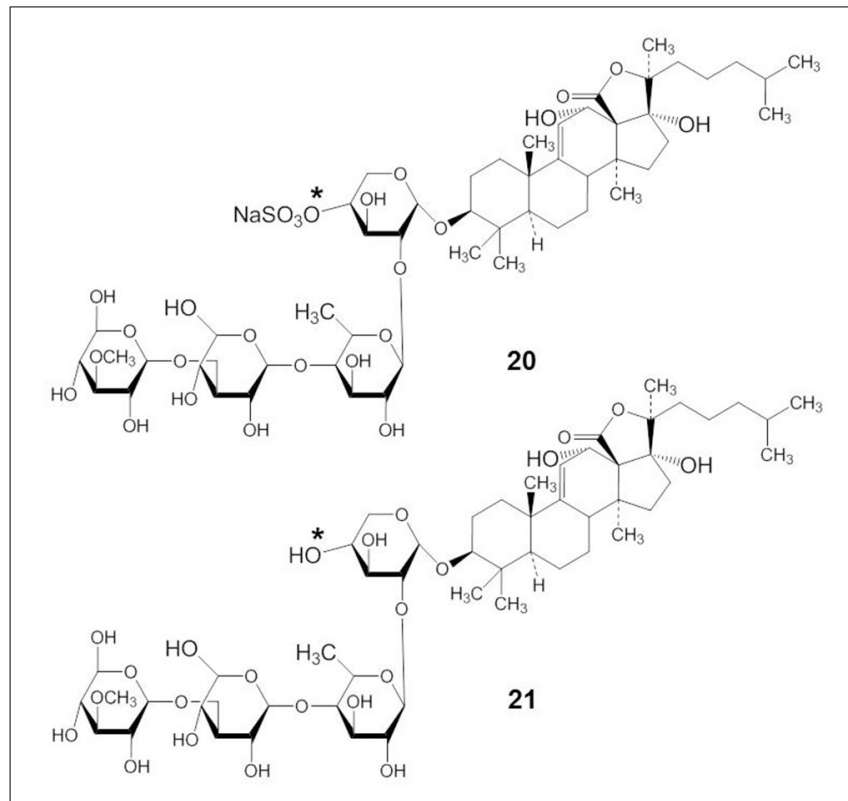

FIGURE 9 | Structures of EA (20) and DSEA (21).

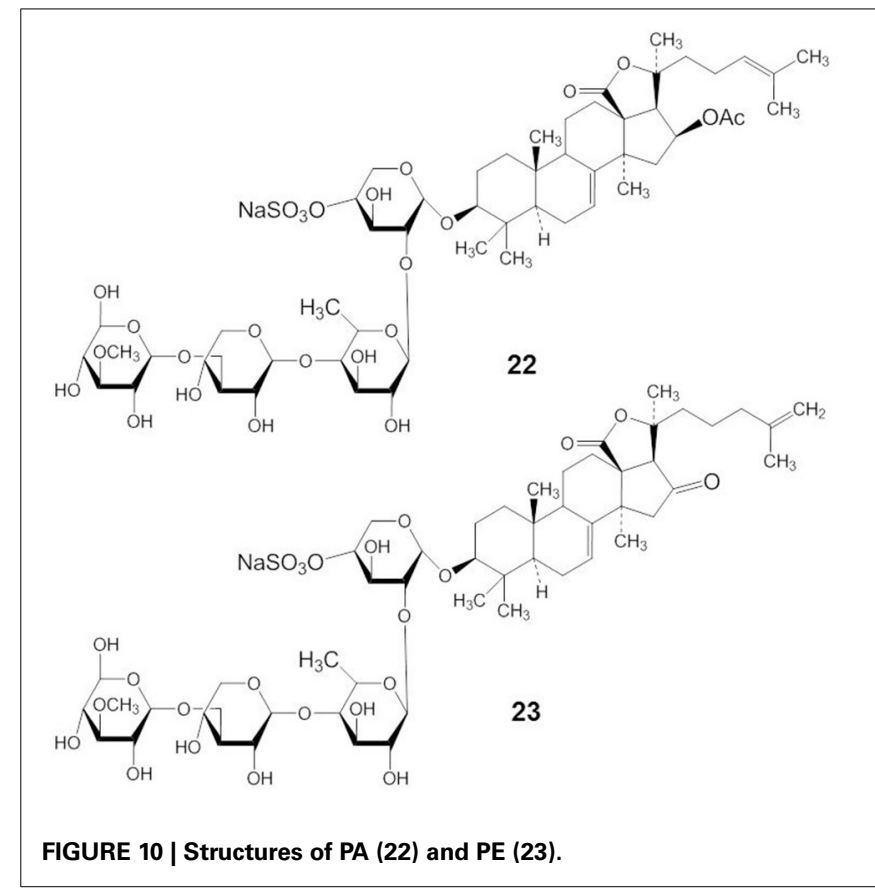

Philinopside E (PE) (compound 23) is a new sulfated saponin from sea cucumbers. PE inhibits cell adhesion, migration, and invasion through the inhibition of vascular endothelial growth factor receptor 2 (VEGFR2) signaling leading to the suppression of Akt, ERK, focal adhesion kinase, and paxillin (Tian et al., 2005). In addition, Tian et al. (2007) have shown that PE specifically interacted with the extracellular domain of the kinase insert domain-containing receptor (KDR) to block its interaction with VEGF and inhibited downstream signaling. More specifically, PE markedly suppressed $\alpha_{\mathrm{V}} \beta_{3}$ integrin-driven downstream signaling as a result of disturbing the physical interaction between KDR and $\alpha_{v} \beta_{3}$ integrin in human microvascular endothelial cells, followed by disruption of the actin cytoskeleton organization and decreased cell adhesion to vitronectin (Tian et al., 2007).

\section{CONCLUSIONS}

Sea cucumbers contain physiologically active triterpene glycosides. Biological effects, including anticancer activities of several marine triterpene glycosides are observed in vitro and in vivo. Research regarding the mechanisms of action of marine triterpene glycosides on membrane transporters is very limited despite extensive studies on similar compounds in plants. Taking into account the structural and functional differences between marine and plant triterpene glycosides, more intensive studies are required with natural marine triterpene glycosides to assess their potential as novel drugs for the treatment of diseases, including cancer. The STC has anticancer activity through the generation of ceramide by a different mechanism from STD because of the sugar moiety. The anticancer effects of frondoside A and cucumariosides might be through inhibition of tumorigenesis and metastasis and modulation of antitumor immune responses. However, both frondoside A and cucumariosides also possess membranolytic, cytotoxic, and apoptotic properties 
with different potencies and mechanisms. Structural differences between frondoside $\mathrm{A}$ and cucumarioside seem to be responsible for their different biological activities. Thus, identification of the structural characteristics controlling the biological activities of marine triterpene glycosides is essential for developing marine drugs.

\section{ACKNOWLEDGMENTS}

This work was supported by the Pioneer Research Center Program through the National Research Foundation of Korea funded by the Ministry of Science, ICT \& Future Planning (20120009583 and 2012-0009664).

\section{REFERENCES}

Agafonova, I. G., Aminin, D. L., Avilov, S. A., and Stonik, V. A. (2003). Influence of cucumariosides upon intracellular $\left[\mathrm{Ca}_{2}^{+}\right]_{i}$ and lysosomal activity of macrophages. J. Agric. Food Chem. 51, 6982-6986. doi: 10.1021/ jf034439x

Al Marzouqi, N., Iratni, R., Nemmar, A., Arafat, K., Ahmed Al Sultan, M., Yasin, J., et al. (2011). Frondoside A inhibits human breast cancer cell survival, migration, invasion and the growth of breast tumor xenografts. Eur. J. Pharmacol. 668, 25-34. doi: 10.1016/j.ejphar.2011.06.023

Aminin, D. L., Agafonova, I. G., Berdyshev, E. V., Isachenko, E. G., Avilov, S. A., and Stonik, V. A. (2001). Immunomodulatory properties of cucumariosides from the edible Far-Eastern holothurian Cucumaria japonica. J. Med. Food 4, 127-135. doi: 10.1089/109662001753165701

Aminin, D. L., Chaykina, E. L., Agafonova, I. G., Avilov, S. A., Kalinin, V. I., and Stonik, V. A. (2010). Antitumor activity of the immunomodulatory lead Cumaside. Int. Immunopharmacol. 10, 648-654. doi: 10.1016/j.intimp.2010.03.003

Aminin, D. L., Gorpenchenko, T. Y., Bulgakov, V. P., Andryjashchenko, P. V., Avilov, S. A., and Kalinin, V. I. (2011). Triterpene glycoside cucumarioside $\mathrm{A}_{2}-2$ from sea cucumber stimulates mouse immune cell adhesion, spreading, and motility. J. Med. Food 14, 594-600. doi: 10.1089/jmf.2010.1274

Aminin, D. L., Pinegin, B. V., Pichugina, L. V., Zaporozhets, T. S., Agafonova, I. G., Boguslavski, V. M., et al. (2006). Immunomodulatory properties of Cumaside. Int. Immunopharmacol. 6, 1070-1082. doi: 10.1016/j.intimp.2006. 01.017

Anisimov, M. M. (1987). Triterpene glycosides and structure-functional properties of biomembranes. Nauchnye Doki. Vyss. Shkoly Biol. Nauki 10, 49-63.

Antonov, A. S., Avilov, S. A., Kalinovsky, A. I., Anastyuk, S. D., Dmitrenok, P. S., Evtushenko, E. V., et al. (2008). Triterpene glycosides from Antartic sea cucumbers. 1. Structure of liouvillosides $A_{1}, A_{2}, A_{3}, B_{1}$, and $B_{2}$ from the sea cucumber Staurocucumis liouvillei: new procedure for separation of highly polar glycoside fractions and taxonomic revision. J. Nat. Prod. 71, 1677-1685. doi: $10.1021 / \mathrm{np} 800173 \mathrm{c}$

Antonov, A. S., Avilov, S. A., Kalinovsky, A. I., Anastyuk, S. D., Dmitrenok, P. S., Kalinin, V. I., et al. (2009). Triterpene glycosides from Antarctic sea cucumbers. 2. Structure of Achlioniceosides $A_{1}, A_{2}$, and $A_{3}$ from the sea cucumber Achlionice violaecuspidata (=Rhipidothuria racowitzai). J. Nat. Prod. 72, 33-38. doi: 10.1021/np800469v

Antonov, A. S., Avilov, S. A., Kalinovsky, A. I., Dmitrenok, P. S., Kalinin, V. I., Taboada, S., et al. (2011). Triterpene glycosides from Antartic sea cucumbers. III. Structures of liouvillosides $\mathrm{A}_{4}$ and $\mathrm{A}_{5}$, two minor disulphated tetraosides containing 3-O-methylquinovose as terminal monosaccharide units from the sea cucumber Staurocucumis liouvillei (Vaney). Nat. Prod. Res. 25, 1324-1333. doi: 10.1080/14786419.2010.531017

Attoub, S., Arafat, K., Gélaude, A., Al Sultan, M. A., Bracke, M., Collin, P., et al. (2013). Frondoside A suppressive effects on lung cancer survival, tumor growth, angiogenesis, invasion, and metastasis. PLoS ONE 8:e53087. doi: 10.1371/journal.pone.0053087

Avilov, S. A., Antonov, A. S., Drozdova, O. A., Kalinin, V. I., Kalinovsky, A. I., Riguera, R., et al. (2000a). Triterpene glycosides from the far eastern sea cucumber Pentamera calcigera II: disulfated glycosides. J. Nat. Prod. 63, 65-71. doi: $10.1021 /$ np9903447
Avilov, S. A., Antonov, A. S., Drozdova, O. A., Kalinin, V. I., Kalinovsky, A. I., Stonik, V. A., et al. (2000b). Triterpene glycosides from the Far Eastern sea cucumber Pentamera calcigera. 1. Monosulfated glycosides and cytotoxicity of their unsulfated derivatives. J. Nat. Prod. 63, 65-71. doi: 10.1021/np99 03447

Avilov, S. A., Antonov, A. S., Silchenko, A. S., Kalinin, V. I., Kalinovsky, A. I., Dmitrenok, P. S., et al. (2003). Triterpene glycosides from the Far Eastern sea cucumber Cucumaria conicospermium. J. Nat. Prod. 66, 910-916. doi: $10.1021 / \mathrm{np} 030005 \mathrm{k}$

Avilov, S. A., Kalinovsky, A. I., Kalinin, V. I., Stonik, V. A., Riguera, R., and Jimenez, C. (1997). Koreoside A, a new nonholostane triterpene glycoside from the sea cucumber Cucumaria koraiensis. J. Nat. Prod. 60, 808-810. doi: $10.1021 / \mathrm{np} 970152 \mathrm{~g}$

Avilov, S. A., Silchenko, A. S., Antonov, A. S., Kalinin, V. I., Kalinovsky, A. I., Smirnov, A. V., et al. (2008). Synaptosides A and $A_{1}$, two triterpene glycosides from the sea cucumber Synapta maculata containing 3-O-methylglucuronic acid and their cytotoxic activity against tumor cells. J. Nat. Prod. 71, 525-531 doi: $10.1021 / \mathrm{np} 070283+$

Avilov, S. A., Stonik, V. A., and Kalinovsky, A. I. (1990). Structures of four new triterpene glycosides from the sea cucumber Cucumaria japonica. Khim. Prirodn. Soedin. 6, 787-792.

Bordbar, S., Anwar, F., and Saari, N. (2011). High-value components and bioactives from sea cucumbers for functional foods- a review. Mar. Drugs 9, 1761-1805. doi: $10.3390 / \mathrm{md} 9101761$

Brown, D. A., and London, E. (1998). Functions of lipid rafts in biological membranes. Annu. Rev. Cell. Dev. Biol. 14, 111-136. doi: 10.1146/annurev.cellbio.14.1.111

Chiludil, H. D., Murray, A. P., Seldes, A. M., and Maier, M. (2003). Biologically active triterpene glycosides from the sea cucumbers (Holothuroidea, Echinodermata). Stud. Nat. Prod. Chem. 28, 587-591. doi: 10.1016/S15725995(03)80150-3

Choi, S. H., Shin, T. J., Hwang, S. H., Lee, B. H., Kang, J., Kim, H. J., et al. (2011b). Ginsenoside $\mathrm{Rg}_{3}$ decelerates hERG $\mathrm{K}^{+}$channel deactivation through Ser631 residue interaction. Eur. J. Pharmacol. 663, 59-67. doi: 10.1016/j.ejphar.2011.05.006

Choi, S. H., Shin, T. J., Lee, B. H., Hwang, S. H., Lee, S. M., Lee, B. C., et al. (2011a). Ginsenoside $\mathrm{Rg}_{3}$ enhances large conductance $\mathrm{Ca}^{2+}$-activated potassium channel currents: a role of Tyr360 residue. Mol. Cells 31, 133-140. doi: 10.1007/s10059-011-0017-7

Colorado-Ríos, J., Muñoz, D., Montoya, G., Márquez, D., Márquez, M. E., López, J., et al. (2013). HPLC-ESI-IT-MS/MS analysis and biological activity of triterpene glycosides from the Colombian marine sponge Ectyoplasia ferox. Mar. Drugs 11, 4815-4833. doi: 10.3390/md11124815

Dang, N. H., Thanh, N. V., Kiem, P. V., Huang, L. M., Minh, C. V., and Kim, Y. H. (2007). Two new triterpene glycosides from the Vietnamese sea cucumber Holothuria scarbra. Arch. Pharm. Res. 30, 1387-1391. doi: 10.1007/BF02977361

Drozdova, O. A., Avilov, S. A., Kalinin, V. I., Kalinovsky, A. I., Stonik, V. A., Rugiera, R., et al. (1997). Cytotoxic triterpene glycosides from Far-Eastern sea cucumber belonging to the genus Cucumaria. Liebigs. Ann. Chem. 11, 2351-2356. doi: 10.1002/jlac.199719971125

Drozdova, O. A., Avilov, S. A., Kalinovsky, A. I., Stonik, V. A., Milgrom, Y. M., and Rashkes, Y. W. (1993). Trisulfated glycosides from the sea cucumber Cucumaria japonica. Khim. Prirodn. Soedin. 3, 369-374.

Fu, Y., Zhou, E., Wei, Z., Liang, D., Wang, W., Wang, T., et al. (2014). Glycyrrhizin inhibits the inflammatory response in mouse mammary epithelial cells and a mouse mastitis model. FEBS J. 281, 2543-2557. doi: 10.1111/febs. 12801

Girard, M., Belanger, J., ApSimon, J. W., Garneau, F. X., Harvey, C., and Brisson, J. R. (1990). Frondoside A, novel triterpene glycoside from the holothurian Cucumaria frondosa. Can. J. Chem. 68, 11-18. doi: 10.1139/v90-003

Goni, F. M., and Alonso, A. (2002). Sphingomyelinases: enzymology and membrane activity. FEBS. Letter. 531, 38-46. doi: 10.1016/S0014-5793(02)03482-8

Gorshkova, I. A., Kalinin, V. I., Gorshkov, B. A., and Stonik, V. A. (1999). Two different modes of inhibition of the rat brain $\mathrm{Na}^{+}, \mathrm{K}^{+}$-ATPase by triterpene glycosides, psolusosides A and B from the holothurian Psolus fabricii. Comp. Biochem. Physiol. C Pharmacol. Toxicol. Endocrinol. 122, 101-108. doi: 10.1016/S0742-8413(98)10085-3

Gulbins, E., and Kolesnick, R. (2002). Acid sphingomyelinase-derived ceramide signaling in apoptosis. Subcell. Biochem. 36, 229-244. doi: 10.1007/0-30647931-1_12 
Hannun, Y. A., and Obeid, L. M. (2008). Principles of bioactive lipid signaling: lessons from sphingolipids. Nat. Rev. Mol. Cell. Biol. 9, 139-150. doi: $10.1038 / \mathrm{nrm} 2329$

Holt, D. M., Ma, X., Kundu, N., Collin, P. D., and Fulton, A. M. (2012). Modulation of host natural killer cell functions in breast cancer via prostaglandin $\mathrm{E}_{2}$ receptors $\mathrm{EP}_{2}$ and $\mathrm{EP}_{4}$. J. Immunother. 35, 179-188. doi: 10.1097/CJI.0b013e318247a5e9

Hwang, J. A., Hwang, M. K., Jang, Y., Lee, E. J., Kim, J. E., Oh, M. H., et al. (2013). 20-O- $\beta$-d-glucopyranosyl-20(S)-protopanaxadiol, a metabolite of ginseng, inhibits colon cancer growth by targeting TRPC channel-mediated calcium influx. J. Nutr. Biochem. 24, 1096-1104. doi: 10.1016/j.jnutbio.2012.08.008

Im, D. S., and Nah, S. Y. (2013). Yin and Yang of ginseng pharmacology: ginsenosides vs gintonin. Acta Pharmacol. Sin. 34, 1367-1373. doi: 10.1038/aps.2013.100

Iñiguez-Martinez, A. M., Guerra-Rivas, G., Rios, T., and Quijano, L. (2005). Triterpenoid oligoglycosides from the sea cucumber Stichopus parvimensis. J. Nat. Prod. 68, 1669-1673. doi: 10.1021/np050196m

Itoh, K., Hara, T., Shiraishi, T., Taniguchi, K., Morimoto, S., and Onishi, T. (1989). Effects of glycyrrhizin and glycyrrhetinic acid on $\mathrm{Na}^{+}-\mathrm{K}^{+}$-ATPase of renal basolateral membranes in vitro. Biochem. Int. 18, 81-89.

Jin, J. O., Shastina, V. V., Shin, S. W., Xu, Q., Park, J. I., Rasskazov, V. A., et al. (2009). Differential effects of triterpene glycosides, frondoside A and cucumarioside $\mathrm{A}_{2}-2$ isolated from sea cucumbers on caspase activation and apoptosis of human leukemia cells. FEBS. Lett. 583, 697-702. doi: 10.1016/j.febslet.2009. 01.010

Kalinin, V. I. (2000). System-theoretical (holistic) approach to the modeling of structural functional relationships of biomolecules and their evolution: an example of triterpene glycosides from sea cucumbers (Echinodermata, Holothurioidea). J. Theor. Biol. 206, 151-168. doi: 10.1006/jtbi.2000.2110

Kalinin, V. I., Aminin, D. L., Avilov, S. A., Silchenko, A. S., and Stonik, V. A. (2008). "Triterpene glycosides from sea cucucmbers (Holothurioidae, Echinodermata), biological activities and functions," in Studies in Natural Product Chemistry (Bioactive Natural Products), ed Atta-ur-Rahman (Amsterdam: Elsevier Science Publisher), 135-196.

Kalinin, V. I., Avilov, S. A., Kalinina, E. Y., Korolkova, O. G., Kalinovsky, A. I., Stonik, V. A., et al. (1997). Structure of eximisoside A, a novel triterpene glycoside from the Far-Eastern sea cucumber Psolus eximius. J. Nat. Prod. 60, 817-819. doi: 10.1021/np9701541

Kalinin, V. I., Ivanchina, N. V., Krasokhin, V. B., Makarieva, T. N., and Stonik, V. A. (2012). Glycosides from marine sponges (Porifera, Demospongiae): structures, taxonomical distribution, biological activities and biological roles. Mar. Drugs 10, 1671-1710. doi: 10.3390/md10081671

Kalinin, V. I., Prokofieva, N. G., Likhatskaya, G. N., Schentsova, E. B., Agafonova, I. G., Avilov, S. A., et al. (1996). Hemolytic activities of triterpene glycosides from holothurian order Dendrochirotida: some trends in the evolution of this group of toxins. Toxicon 34, 475-483. doi: 10.1016/0041-0101(95)00142-5

Kalinin, V. I., Silchenko, A. S., Avilov, S. A., Stonik, V. A., and Smirnov, A. V. (2005). Sea cucumbers triterpene glycosides, the recent progress in structural elucidation and chemotaxonomy. Phytochem. Rev. 4, 221-236. doi: 10.1007/s11101005-1354-y

Kalinin, V. I., Volkova, O. V., Likhatskaya, G. N., Prokofieva, N. G., Agafonova, I. G., Anisimov, M. M., et al. (1992). Hemolytic activity of triterpene glycosides from Cucumariidae family holothurians and evolution of this group of toxins. J. Nat. Toxins 1, 17-30.

Kerr, R. G., and Chen, Z. (1995). In vivo and in vitro biosynthesis of saponins in sea cucumbers. J. Nat. Prod. 58, 172-176. doi: 10.1021/np50116a002

Kim, S., Ahn, K., Oh, T. H., Nah, S. Y., and Rhim, H. (2002). Inhibitory effect of ginsenosides on NMDA receptor-mediated signals in rat hippocampal neurons. Biochem. Biophys. Res. Commun. 296, 247-254. doi: 10.1016/S0006291X(02)00870-7

Kim, S. K., and Himaya, S. W. (2012). Triterpene glycosides from sea cucumbers and their biological activities. Adv. Food Nutr. Res. 65, 297-319. doi: 10.1016/B978-0-12-416003-3.00020-2

Kitagawa, I. (1988). Research of biologically active marine natural products. Yakugaku. Zasshi. 108, 398-416.

Kitagawa, I., Kobayashi, M., Inamoto, T., Yosuzawa, T., and Kyogoku, Y. (1981). The structures of six antifungal oligoglycosides, Stichlorosides $A_{1}, A_{2}, B_{1}, B_{2}$, $\mathrm{C}_{1}$ and $\mathrm{C}_{2}$ from the sea cucumber Stichopus chloronotus (Brandt). Chem. Phar. Bull. 29, 2387-2391 doi: 10.1248/cpb.29.2387
Kolesnick, R. N., Goni, F. M., and Alonso, A. (2000). Compartmentalization of ceramide signaling: physical foundations and biological effects. J. Cell. Physiol. 184, 285-300. doi: 10.1002/1097-4652(200009)184:3\&lt;285::AIDJCP2\&gt;3.0.CO;2-3

Kuznetsova, T. A., Anisimov, M. M., Popov, A. M., Baranova, S. I., Afiyatullov, S. H., Kapustina, I. I., et al. (1982). A comparative study in vitro of physiological activity of triterpene glycosides of marine invertebrates of echinoderm type. Comp. Biochem. Physiol. C. 73, 41-43. doi: 10.1016/0306-4492(82)90165-4

Lee, B. H., Choi, S. H., Hwang, S. H., Kim, H. J., Lee, S. M., Kim, H. C., et al. (2013a). Effects of ginsenoside $\operatorname{Rg}_{3}$ on $\alpha_{9} \alpha_{10}$ nicotinic acetylcholine receptor-mediated ion currents. Biol. Pharm. Bull. 36, 812-818. doi: 10.1248/bpb.b12-01009

Lee, B. H., Kim, H. J., Chung, L., and Nah, S. Y. (2013b). Ginsenoside $\operatorname{Rg}_{3}$ regulates GABA receptor channel activity: involvement of interaction with the $\gamma_{2}$ subunit. Eur. J. Pharmacol. 705, 119-125. doi: 10.1016/j.ejphar.2013. 02.040

Lee, E., Kim, S., Chung, K. C., Choo, M. K., Kim, D. H., Nam, G., et al. (2006). 20(S)-ginsenoside $\mathrm{Rh}_{2}$, a newly identified active ingredient of ginseng, inhibits NMDA receptors in cultured rat hippocampal neurons. Eur. J. Pharmacol. 536, 69-77. doi: 10.1016/j.ejphar.2006.02.038

Lee, J. H., Choi, S. H., Lee, B. H., Shin, T. J., Pyo, M. K., Hwang, S. H., et al. (2009). The effects of ginsenoside $\mathrm{Rg}_{3}$ on human Kv1.4 channel currents without the N-terminal rapid inactivation domain. Biol. Pharm. Bull. 32, 614-618. doi: $10.1248 / \mathrm{bpb} .32 .614$

Lee, J. H., Lee, B. H., Choi, S. H., Yoon, I. S., Shin, T. J., Pyo, M. K., et al. (2008). Involvement of batrachotoxin binding sites in ginsenosidemediated voltage-gated $\mathrm{Na}^{+}$channel regulation. Brain Res. 1203, 61-67. doi: 10.1016/j.brainres.2008.01.078

Levade, T., and Jaffrezou, J. P. (1999). Signalling sphingomyelinases: which, where, how and why? Biochim. Biophys. Acta 1438, 1-17. doi: 10.1016/S13881981(99)00038-4

Li, M., Ma, R. N., Li, L. H., Qu, Y. Z., and Gao, G. D. (2013). Astragaloside IV reduces cerebral edema post-ischemia/reperfusion correlating the suppression of MMP-9 and AQP4. Eur. J. Pharmacol. 715, 189-195. doi: 10.1016/j.ejphar.2013.05.022

Li, M., Miao, Z. H., Chen, Z., Chen, Q., Gui, M., Lin, L. P., et al. (2010). Echinoside A, a new marine-derived anticancer saponin, targets topoisomerase $2 \alpha$ by unique interference with its DNA binding and catalytic cycle. Ann. Oncol. 21, 597-607. doi: 10.1093/annonc/mdp335

Li, X., Roginsky, A. B., Ding, X. Z., Woodward, C., Collin, P., and Newman, R. A. (2008). Review of the apoptosis pathways in pancreatic cancer and the antiapoptotic effects of the novel sea cucumber compound, Frondoside A. Ann. N.Y. Acad. Sci. 1138, 181-198. doi: 10.1196/annals.1414.025

Li, X. X., Davis, B., Haridas, V., Gutterman, J. U., and Colombini, M. (2005). Proapoptotic triterpene electrophiles (avicins) form channels in membranes: cholesterol dependence. Biophys. J. 88, 2577-2584. doi: 10.1529/biophysj.104.049403

Lin, Z. Y., Chen, L. M., Zhang, J., Pan, X. D., Zhu, Y. G., Ye, Q. Y., et al. (2012). Ginsenoside $R b_{1}$ selectively inhibits the activity of L-type voltage-gated calcium channels in cultured rat hippocampal neurons. Acta Pharmacol. Sin. 33, 438-444. doi: 10.1038/aps.2011.181

Lorent, J., Le Duff, C. S., Quetin-Leclercq, J., and Mingeot-Leclercq, M. P. (2013). Induction of highly curved structures in relation to membrane permeabilization and budding by the triterpenoid saponins, $\alpha$ - and $\delta$-Hederin. J. Biol. Chem. 288, 14000-14017. doi: 10.1074/jbc.M112.407635

Ma, X., Kundu, N., Collin, P. D., Goloubeva, O., and Fulton, A. M. (2012) Frondoside $\mathrm{A}$ inhibits breast cancer metastasis and antagonizes prostaglandin $\mathrm{E}$ receptors $\mathrm{EP}_{4}$ and $\mathrm{EP}_{2}$. Breast Cancer Res. Treat. 132, 1001-1008. doi: 10.1007/s10549-011-1675-Z

Maltsev, I. I., Stekhova, S. I., Schentsova, E. B., Anisimov, M. M., and Stonik, V. A. (1985). Antimicrobial activities of glycosides from the sea cucumbers of family Stichopodidae. Khim. Pharm. Zhurn. 19, 54-56.

McManus, O. B., Harris, G. H., Giangiacomo, K. M., Feigenbaum, P., Reuben, J. P., Addy, M. E., et al. (1993). An activator of calcium-dependent potassium channels isolated from a medicinal herb. Biochemistry 32, 6128-6133. doi: 10.1021/bi00075a002

Menchinskaya, E. S., Pislyagin, E. A., Kovalchuk, S. N., Davydova, V. N., Silchenko, A. S., Avilov, S. A., et al. (2013). Antitumor activity of cucumarioside A2-2. Chemotherapy 59, 181-191. doi: 10.1159/000354156 
Mimaki, Y., Yokosuka, A., Kuroda, M., and Sashida, Y. (2001). Cytotoxic activities and structure-cytotoxic relationships of steroidal saponins. Biol. Pharm. Bull. 24, 1286-1289. doi: 10.1248/bpb.24.1286

Moraes, G., Northcote, P. T., Silchenko, A. S., Antonov, A. S., Kalinovsky, A. I., Dmitrenok, P. S., et al. (2005). Mollisosides A, $B_{1}$, and $B_{2}$ : minor triterpene glycosides from the New Zealand and South Australian sea cucumber Australostichopus mollis. J. Nat. Prod. 68, 842-847. doi: 10.1021/ np050049o

Nah, S. Y. (2014). Ginseng ginsenoside pharmacology in the nervous system: involvement in the regulation of ion channels and receptors. Front. Physiol. 5:98 doi: $10.3389 /$ fphys. 2014.00098

Nigrelli, R. F. (1952). The effect of holothurin on fish and mice with Sarcoma-180. Zoologica 37, 89-90.

Nigrelli, R. F., Stempien, M. F. Jr., Ruggieri, G. D., Liguori, V. R., and Cecil, J. T. (1967). Substances of potential biomedical importance from marine organisms. Fed. Proc. 26, 1197-1205.

Pan, X. Y., Guo, H., Han, J., Hao, F., An, Y., Xu, Y., et al. (2012). Ginsenoside $\mathrm{Rg}_{3}$ attenuates cell migration via inhibition of aquaporin 1 expression in PC-3M prostate cancer cells. Eur. J. Pharmacol. 683, 27-34. doi: 10.1016/j.ejphar.2012.02.040

Park, E. S., Yun, S. H., Shin, S. W., Kwak, J. Y., and Park, J. I. (2012a). Induction of apoptosis and antitumor activity by stichoposide D through the generation of ceramide in human leukemia cells. J. Life. Sci. 22, 760-771. doi: 10.5352/JLS.2012.22.6.760

Park, S. Y., Kim, Y. H., Kim, Y., and Lee, S. J. (2012b). Frondoside A has an antiinvasive effect by inhibiting TPA-induced MMP-9 activation via NF-кB and AP-1 signaling in human breast cancer cells. Int. J. Oncol. 41, 933-940. doi: 10.3892/ijo.2012.1518

Pislyagin, E. A., Gladkikh, R. V., Kapustina, I. I., Kim, N. Y., Shevchenko, V. P., Nagaev, I. Y., et al. (2012). Interaction of holothurian triterpene glycoside with biomembranes of mouse immune cells. Int. Immunopharmacol. 14, 1-8. doi: 10.1016/j.intimp.2012.05.020

Polikarpova, S. I., Volkova, O. N., Sedov, A. M., Stonik, V. A., and Likhoded, V. G. (1990). Cytogenetic study of the mutagenicity of cucumarioside. Genetika 26 1682-1685.

Robertson, F. M., Simeone, A. M., Lucci, A., McMurray, J. S., Ghosh, S., and Cristofanilli, M. (2010). Differential regulation of the aggressive phenotype of inflammatory breast cancer cells by prostanoid receptors $\mathrm{EP}_{3}$ and $\mathrm{EP}_{4}$. Cancer 116, 2806-2814. doi: 10.1002/cncr.25167

Roginsky, A. B., Ding, X.-Z., Woodward, C., Ujiki, M. B., Singh, B., Bell, R. H. Jr., et al. (2010). Anti-pancreatic cancer effects of a polar extract from the edible sea cucumber, Cucumaria frondosa. Pancreas 39, 646-652. doi: 10.1097/MPA.0b013e3181c72baf

Shang, W., Yang, Y., Zhou, L., Jiang, B., Jin, H., and Chen, M. (2008). Ginsenoside $\mathrm{Rb}_{1}$ stimulates glucose uptake through insulin-like signaling pathway in 3T3-L1 adipocytes. J. Endocrinol. 198, 561-569. doi: 10.1677/JOE-08-0104

Silchenko, A. S., Avilov, S. A., Antonov, A. A., Kalinin, V. I., Kalinovsky, A. I., Smimov, A. V., et al. (2002). Triterpene glycosides from the deep-water NorthPacific sea cucumber Synallactes nozawai Mitsukuri. J. Nat. Prod. 65, 1802-1808. doi: $10.1021 / \mathrm{np} 0202881$

Silchenko, A. S., Avilov, S. A., Antonov, A. S., Kalinovsky, A. I., Dmitrenok, P. S., Kalinin, V. I., et al. (2005a). Glycosides from the sea cucumber Cucumaria frondosa. III. Structure of frondosides $A_{2}-1, A_{2}-2, A_{2}-3$, and $A_{2}-6$, four new minor monosulfated triterpene glycosides. Can. J. Chem. 83, 21-27. doi: 10.1139/ v04-163

Silchenko, A. S., Avilov, S. A., Antonov, A. S., Kalinovsky, A. I., Dmitrenok, P. S., Kalinin, V. I., et al. (2005b). Glycosides from the sea cucumber Cucumaria frondosa. IV. Structure of frondosides $\mathrm{A}_{2}-4, \mathrm{~A}_{2}-7$, and $\mathrm{A}_{2}-8$, three new minor monosulfated triterpene glycosides. Can. J. Chem. 83, 2120-2126. doi: 10.1139/ v05-243

Silchenko, A. S., Avilov, S. A., Kalinin, V. I., Kalinovsky, A. I., Dmitrenok, P. S., Fedorov, S. N., et al. (2008). Constituents of the sea cucumber Cucumaria okhotensis. Structures of okhotosides $\mathrm{B}_{1}-\mathrm{B}_{3}$ and cytotoxic activities of some glycosides from this species. J. Nat. Prod. 71, 351-356. doi: 10.1021/np0705413

Silchenko, A. S., Avilov, S. A., Kalinin, V. I., Stonik, V. A., Kalinovsky, A. I., Dmitrenok, P. S., et al. (2007a). Monosulfated triterpene glycosides from Cucumaria okhotensis Levin et Stepanov, a new species of sea cucumbers from sea of Okhotsk. Russ. J. Bioorg. Chem. 33, 73-82, doi: $10.1134 /$ S1068162007010098
Silchenko, A. S., Avilov, S. A., Kalinovsky, A. I., Dmitrenok, P. S., Kalinin, V. I., Morre, J., et al. (2007b). Glycosides from the North Atlantic sea cucumber Cucumaria frondosa $\mathrm{V}$ - Structures of five new minor trisulfated triterpene oligoglycosides, frondosides $\mathrm{A}_{7}-1, \mathrm{~A}_{7}-2, \mathrm{~A}_{7}-3, \mathrm{~A}_{7}-4$, and isofrondoside C. Can. J. Chem. 85, 626-636. doi: 10.1139/v07-087

Silchenko, A. S., Kalinovsky, A. I., Avilov, S. A., Andryjaschenko, P. V., Dmitrenok, P. S., Martyyas, E. A., et al. (2012a). Triterpene glycosides from the sea cucumber Eupentacta fraudatrix. Structure and biological action of cucumariosides $A_{1}, A_{3}, A_{4}, A_{5}, A_{6}, A_{12}$ and $A_{15}$, seven new minor non-sulfated tetraosides and unprecedented 25-keto, 27-norholostane aglycone. Nat. Prod. Commun. 7, $517-525$.

Silchenko, A. S., Kalinovsky, A. I., Avilov, S. A., Andryjaschenko, P. V., Dmitrenok, P. S., Martyyas, E. A., et al. (2012b). Triterpene glycosides from the sea cucumber Eupentacta fraudatrix. Structure and cytotoxic action of cucumariosides $\mathrm{A}_{2}$, $A_{7}, A_{9}, A_{10}, A_{11}, A_{13}$ and $A_{14}$, seven new minor non-sulfated tetraosides and an aglycone with an uncommon 18-hydroxy group. Nat. Prod. Commun. 7, 845-852.

Silchenko, A. S., Kalinovsky, A. I., Avilov, S. A., Andryjaschenko, P. V., Dmitrenok, P. S., Martyyas, E. A., et al. (2012c). Triterpene glycosides from the sea cucumber Eupentacta fraudatrix. Structure and biological activity of cucumariosides $\mathrm{B}_{1}$ and $\mathrm{B}_{2}$, two new minor non-sulfated unprecedented triosides. Nat. Prod. Commun. 7, 1157-1162.

Silchenko, A. S., Kalinovsky, A. I., Avilov, S. A., Andryjaschenko, P. V., Dmitrenok, P. S., Martyyas, E. A., et al. (2013a). Structures and biological activities of typicosides $A_{1}, A_{2}, B_{1}, C_{1}$ and $C_{2}$, triterpene glycosides from the sea cucumber Actinocucumis typica. Nat. Prod. Commun. 8, 301-310.

Silchenko, A. S., Kalinovsky, A. I., Avilov, S. A., Andryjaschenko, P. V., Dmitrenok, P. S., Martyyas, E. A., et al. (2013b). Triterpene glycosides from the sea cucumber Eupentacta fraudatrix. Structure and biological action of cucumariosides $\mathrm{I}_{1}, \mathrm{I}_{3}$, $\mathrm{I}_{4}$, three new minor disulfated pentaosides. Nat. Prod. Commun. 8, 1053-1058.

Silchenko, A. S., Kalinovsky, A. I., Avilov, S. A., Andryjaschenko, P. V., Dmitrenok P. S., Menchinskaya, E. S., et al. (2013c). Structure of cucumarioside $\mathrm{I}_{2}$ from the sea cucumber Eupentacta fraudatrix (Djakonov et Baranova) and cytotoxic and immunostimulatory activities of this saponin and relative compounds. Nat Prod. Res. 27, 1776-1783. doi: 10.1080/14786419.2013.778851

Silchenko, A. S., Kalinovsky, A. I., Avilov, S. A., Andryjaschenko, P. V., Dmitrenok, P. S., Yurchenko, E. A., et al. (2011). Structure of cucumariosides $\mathrm{H}_{5}, \mathrm{H}_{6}, \mathrm{H}_{7}$ and $\mathrm{H}_{8}$, triterpene glycosides from the sea cucumber Eupentacta fraudatrix and unprecedented aglycone with 16,22-epoxy-group. Nat. Prod. Commun. 6, 1075-1082.

Silchenko, A. S., Kalinovsky, A. I., Avilov, S. A., Andryjaschenko, P. V., Dmitrenok, P. S., Yurchenko, E. A., et al. (2012d). Structures and cytotoxic properties of cucumariosides $\mathrm{H}_{2}, \mathrm{H}_{3}$ and $\mathrm{H}_{4}$ from the sea cucumber Eupentacta fraudatrix. Nat. Prod. Res. 26, 1765-1774. doi: 10.1080/14786419.2011.602637

Silchenko, A. S., Kalinovsky, A. I., Avilov, S. A., Andryjaschenko, P. V., Dmitrenok, P. S., Yurchenko, E. A., et al. (2013d). Structure and biological action of cladolosides $\mathrm{B}_{1}, \mathrm{~B}_{2}, \mathrm{C}_{1}, \mathrm{C}_{2}$ and $\mathrm{D}$, six new triterpene glycosides from the sea cucumber Cladolabes schmeltzii. Nat. Prod. Commun. 8, 1527-1534.

Silchenko, A. S., Stonik, V. A., Avilov, S. A., Kalinin, V. I., Kalinovsky, A. I., Zaharenko, A. M., et al. (2005c). Holothurins $B_{2}, B_{3}$, and $B_{4}$, new triterpene glycosides from Mediterranean sea cucumbers of the genus holothuria. J. Nat. Prod. 68, 564-567. doi: 10.1021/np049631n

Stonik, V. A. (1986). Some terpenoid and steroid derivatives from echinoderms and sponges. Pure Appl. Chem. 58, 423-436.

Stonik, V. A., Kalinin, V. I., and Avilov, S. A. (1999). Toxins from sea cucumbers (holothuroids): chemical structures, properties, taxonomic distribution, biosynthesis and evolution. J. Nat. Toxins 8, 235-248.

Stonik, V. A., Maltsev, I. I., and Elyakov, G. B. (1982b). Structures of thelenotosideA and thelenoside-B from the sea cucumber Thelenota ananas. Chem. Nat. Prod. 624-627.

Stonik, V. A., Maltsev, I. I., Kalinovsky, A. I., Conde, K., and Elyakov, G. B. (1982a). Glycosides of marine- invertebrates. XI. The two novel triterpene glycosides from holothurian of Stichopodidae family. Chem. Nat. Prod. 194-199.

Strum, J. C., Ghosh, S., and Bell, R. M. (1997). Lipid second messengers. A role in cell growth regulation and cell cycle regulation. Adv. Exp. Mol. Biol. 407, 421-431. doi: 10.1007/978-1-4899-1813-0_63

Sullivan, T. D., Ladue, K. T., and Nigrelli, R. F. (1955). The effects of holothurin, a steroid saponin of animal origin, on Krebs-2 ascites tumors in Swiss mice. Zoologica 40, 49-52. 
Taha, T. A., Mullen, T. D., and Obeid, L. M. (2006). A house divided: ceramide, sphingosine, and sphingosine-1-phosphate in programmed cell death. Biochim. Biophys. Acta 1758, 2027-2036. doi: 10.1016/j.bbamem.2006.10.018

Tian, F., Zhang, X., Tong, Y., Yi, Y., Zhang, S., Li, L., et al. (2005). PE, a new sulfated saponin from sea cucumber, exhibits anti-angiogenetic and antitumor activities in vitro and in vivo. Cancer Biol. Ther. 4, 874-882. doi: 10.4161/cbt.4.8.1917

Tian, F., Zhu, C. H., Zhang, X. W., Xie, X., Xin, X. L., Yi, Y. H., et al. (2007). Phillinopside E, a new sulfated saponin from sea cucumber, blocks the interaction between kinase insert domain-containing receptor (KDR) and $\alpha_{v} \beta_{3}$ integrin via binding to the extracellular domain of KDR. Mol. Pharmacol. 72, 545-552. doi: 10.1124/mol.107.036350

Timoshenko, A. V., Xu, G., Chakrabarti, S., Lala, P. K., and Chakraborty, C. (2003). Role of prostaglandin $\mathrm{E}_{2}$ receptors in migration of murine and human breast cancer cells. Exp. Cell Res. 289, 265-274. doi: 10.1016/S0014-4827(03)00269-6

Tong, Y., Zhang, X., Tian, F., Yi, Y., Xu, Q., Li, L., et al. (2005). Philinopside A, a novel marine derived compound possessing dual anti-angiogenetic and antitumor effects. Int. J. Cancer 114, 843-853. doi: 10.1002/ijc.20804

Uyama, Y., Imaizumi, Y., and Watanabe, M. (1992). Effects of cyclopiazonic acid, a novel $\mathrm{Ca}^{2+}$-ATPase inhibitor, on contractile responses in skinned ileal smooth muscle. Br. J. Pharmacol. 106, 208-214. doi: 10.1111/j.14765381.1992.tb14316.x

Verbist, J. E. (1993). "Pharmacological effects of compounds from Echinoderms," in Echinoderm Studies, Vol. 4, eds M. Jangoux and J. M. Lawrence (Rotterdam; Brookfild: A. A. Balkema), 111-186.

Wang, D., and Dubois, R. N. (2010). Eicosanoids and cancer. Nat. Rev. Cancer 10, 182-192. doi: 10.1038/nrc2809

Wang, Y. G., Zima, A. V., Ji, X., Pabbidi, R., Blatter, L. A., and Lipsius, S. L. (2008). Ginsenoside Re suppresses electromechanical alternans in cat and human cardiomyocytes. Am. J. Physiol. Heart Circ. Physiol. 295, H851-H859. doi: 10.1152/ajpheart.01242.2007

Wink, M., Ashour, M. L., and El-Readi, M. Z. (2012). Secondary metabolites from plants inhibiting ABC transporters and reversing resistance of cancer cells and microbes to cytotoxic and antimicrobial agents. Front. Microbiol. 3:130. doi: 10.3389/fmicb.2012.00130

Wong, V. K., Li, T., Law, B. Y., Ma, E. D., Yip, N. C., Michelangeli, F., et al. (2013). Saikosaponin-d, a novel SERCA inhibitor, induces autophagic cell death in apoptosis-defective cells. Cell Death Dis. 11, e720. doi: 10.1038/cddis.2013.217

$\mathrm{Xu}, \mathrm{L}$., and Huang, S. P. (2012). Effect of the ginsenoside $\mathrm{Rb}_{1}$ on the spontaneous contraction of intestinal smooth muscle in mice. World J. Gastroenterol. 18, 5462-5469. doi: 10.3748/wjg.v18.i38.5462

Xu, X. L., Chen, X. J., Ji, H., Li, P., Bian, Y. Y., Yang, D., et al. (2008). Astragaloside IV improved intracellular calcium handling in hypoxia-reoxygenated cardiomyocytes via the sarcoplasmic reticulum Ca-ATPase. Pharmacology 81, 325-332. doi: $10.1159 / 000121335$

Yamasaki, Y., Ito, K., Enomoto, Y., and Sutko, J. L. (1987). Alterations by saponins of passive $\mathrm{Ca}^{2+}$ permeability and $\mathrm{Na}^{+}-\mathrm{Ca}^{2+}$ exchange activity of canine cardiac sarcolemmal vesicles. Biochim. Biophys. Acta 897, 481-487. doi: 10.1016/00052736(87)90445-7

Yun, S. H. (2014). Study on the Molecular Mechanisms for Antitumor Activity of Stichoposide D, an Extract from Sea Cucumbers. Ph.D. Thesis, Dong-A University, Busan, Korea.
Yun, S. H., Park, E. S., Shin, S. W., Na, W. Y., Han, J. Y., Jeong, J. S., et al. (2012). Stichoposide $\mathrm{C}$ induces apoptosis through the generation of ceramide in leukemia and colorectal cancer cells and shows in vivo antitumor activity. Clin. Cancer Res. 18, 5934-5948. doi: 10.1158/1078-0432.CCR12-0655

Yun, U. J., Lee, J. H., Koo, K. H., Ye, S. K., Kim, S. Y., Lee, C. H., et al. (2013). Lipid raft modulation by $\mathrm{Rp}_{1}$ reverses multidrug resistance via inactivating MDR-1 and Src inhibition. Biochem. Pharmacol. 85, 1441-1453. doi: 10.1016/j.bcp.2013.02.025

Zhang, S. H., Li, L., Yi, Y. H., and Sun, P. (2006a). Philipnosides E and F, two new sulfated triterpene glycosides from the sea cucumber Pentacta quadrangularis. Nat. Prod. Res. 20, 399-407. doi: 10.1080/14786410500185584

Zhang, S. Y., Yi, Y. H., and Tang, H. F. (2006b). Bioactive triterpene glycosides from the sea cucumber Holothuria fuscocinerea. J. Nat. Prod. 69, 1492-1495. doi: 10.1021/np060106t

Zhang, S. Y., Yi, Y. H., and Tang, H. F. (2006c). Cytotoxic sulfated triterpene glycosides from the sea cucumber Pseudocolochirus violaceus. Chem. Biodivers. 3, 807-817. doi: 10.1002/cbdv.200690083

Zhang, S. Y., Yi, Y., Tang, H. F., Li, L., Sun, P., and Wu, J. (2006d). Two new bioactive triterpene glycosides from the sea cucumber Pseudocolochirus violaceus. J. Asian Nat. Prod. Res. 8, 1-8. doi: 10.1080/10286020500034972

Zhao, Q., Liu, Z., Xue, Y., Wang, J., Li, H., Tang, Q., et al. (2011). Dsechinoside A, a new triterpene glycoside derived from sea cucumber, exhibits antimetastatic activity via the inhibition of NF-кB-dependent MMP-9 and VEGF expressions. J. Zhejang Univ. Sci. B 12, 534-544. doi: 10.1631/jzus. B1000217

Zhao, Q., Xue, Y., Wang, J., Li, H., Long, T., Li, Z., et al. (2012). In vitro and in vivo anti-tumour activities of echinoside $\mathrm{A}$ and ds-echinoside $\mathrm{A}$ from Pearnonothuria graeffei. J. Sci. Food. Agric. 92, 965-974. doi: 10.1002/ jsfa.4678

Zhou, Z., Yi, Y., Wu, H., Yao, X., Du, L., Jiuhong, W., et al. (2005). Intercedensides D-I, cytotoxic triterpene glycosides from the sea cucumber Mensamaria intercedens Lampert. J. Nat. Prod. 68, 540-546. doi: 10.1021/np040205b

Conflict of Interest Statement: The authors declare that the research was conducted in the absence of any commercial or financial relationships that could be construed as a potential conflict of interest.

Received: 28 June 2014; accepted: 21 August 2014; published online: 09 September 2014.

Citation: Park J-I, Bae H-R, Kim CG, Stonik VA and Kwak J-Y (2014) Relationships between chemical structures and functions of triterpene glycosides isolated from sea cucumbers. Front. Chem. 2:77. doi: 10.3389/fchem.2014.00077

This article was submitted to Chemical Biology, a section of the journal Frontiers in Chemistry.

Copyright (c) 2014 Park, Bae, Kim, Stonik and Kwak. This is an open-access article distributed under the terms of the Creative Commons Attribution License (CC BY). The use, distribution or reproduction in other forums is permitted, provided the original author(s) or licensor are credited and that the original publication in this journal is cited, in accordance with accepted academic practice. No use, distribution or reproduction is permitted which does not comply with these terms. 